\title{
Bargaining for a New Fiscal Pact in Mexico
}

\author{
Steven B. Webb and Christian Y. Gonzalez \\ World Bank, 1818 H Street NW \\ Washington DC 20433, USA \\ swebb@worldbank.org \\ cgonzalez@worldbank.org
}

\begin{abstract}
This paper considers the malaise with the present set-up of fiscal federalism in Mexico from the points of view of the main players - the federal government, the states, the municipalities, and the citizen voters - in order to identify the areas of potential common interest as well as the direct conflicts. There is a zero-sum game on some issues, like the size of aggregate transfers, but not on others, like raising tax collection and improving accountability for service delivery. The paper considers bargain packages that combine mutually beneficial changes with resolutions to zero-sum games and thus might obtain broad enough political support. The bargaining packages are analyzed in two main tracks - one concerning tax assignments, revenue sharing and tax administration, and another concerning the conjunction of earmarked transfers and accountability for service provision. An important result is that almost all states would find it fiscally attractive to impose a sales tax that replaced part of the federal value-added tax, even if the federal government reduced revenue sharing enough to cover half the cost of reducing the value-added tax rate to make room for the state tax.
\end{abstract}

World Bank Policy Research Working Paper 3284, April 2004

The Policy Research Working Paper Series disseminates the findings of work in progress to encourage the exchange of ideas about development issues. An objective of the series is to get the findings out quickly, even if the presentations are less than fully polished. The papers carry the names of the authors and should be cited accordingly. The findings, interpretations, and conclusions expressed in this paper are entirely those of the authors. They do not necessarily represent the view of the World Bank, its Executive Directors, or the countries they represent. Policy Research Working Papers are available online at http://econ.worldbank.org. 


\title{
Bargaining for a New Fiscal Pact in Mexico
}

\author{
Steven B. Webb and Christian Y. Gonzalez ${ }^{1}$
}

\section{Introduction}

The federal government and most of the states are dissatisfied with the present set-up of fiscal federalism in Mexico. On some issues, like the aggregate size of transfers, the gain of one government would come at the direct expense of another. On many other issues, however, like raising tax collection and improving accountability for service delivery, there is more common interest than conflict. The purpose of this paper is to assess the interests of the various governments and others involved in order to identify some possible strategies for revising the fiscal pact in harmony with the interests at all levels, including those of the citizens. It assumes that the reader is familiar with the main features of Mexican federalism. ${ }^{2}$

Federal democracies are exceptionally complex systems, requiring repeated realignment to achieve a workable balance of autonomy and coordination between governments. Even after more than two centuries, marked at times with bloody conflict, the United States is still ironing out problems with its fiscal federalism. Until a decade ago in Mexico, the dominance of a single party provided a mechanism to resolve many of the problems outside the official channels. Since then the opening of full political competition in most political arenas has increased democracy but also led to divided governments and ended the chance for a single party to coordinate between governments. The reinvention of Mexico's fiscal federalism for the new political context is already underway, and this paper discusses some key items on the agenda.

\section{The Status Quo and the Desire for Change}

To understand the motives for change and avenues of political feasibility, this section looks at the status quo from four points of view - those of the citizens, the federal government, the states, and the municipalities.

Mexican citizens are clearly not satisfied with the public sector as a whole, although it has many excellent and dedicated personnel and many good programs. Too often public sector activities are counterproductive or even corrupt. Those who (have to) pay taxes feel cheated not only by the often inadequate and inefficient public services received in return, but also by the knowledge that many others escape paying and that the funds paid often go for local services in distant parts of the country. What is worse, the system typically leaves citizens with no recourse - no voice and no viable exit options, other than emigration abroad. This pattern runs counter to the experiences elsewhere in Latin America, showing that more control and accountability at the level of the service delivery unit (school, hospital, etc.) leads to better

\footnotetext{
${ }^{1}$ Opinions in this paper are those of the authors and do not reflect official positions of the World Bank. We received helpful comments from Julio Cordoba, Joost Draaisma, Fernando Elizondo Barragán, Jonas Frank, José Antonio Gonzalez, Eduardo Guerrero, and David Rosenblatt, who are nevertheless not responsible for any remaining errors.

${ }^{2}$ For a summary of Mexican federalism, see Steven B. Webb, "Decentralization", in Giugale, Lafourcade, and Nguyen, ed., Mexico: A Comprehensive Development Agenda for the New Era, Washington, DC: World Bank, 2001; and M. Giugale and S. B. Webb, ed., Achievements and Challenges of Fiscal Decentralization: Lessons from Mexico, Washington, DC: World Bank, 2000.
} 
service (Winkler, 2000). While these grievances are not all the fault of problems with federalism, they are exactly the problems that advocates of fiscal federalism claim it can address - improving government accountability, giving citizens more voice and choice of exit, and strengthening the connection between the payment of taxes and the receipt of services.

What citizen taxpayers want is reasonable, although difficult to achieve: more and better service for the money paid in taxes (and earned from the national patrimony, like oil), more accountability and less corruption at all levels of government, lower tax rates, and a fairer tax burden, with less evasion and with more of the funds going to finance local activities, carried out by officials with local accountability. While reform of fiscal federalism can hardly solve all these problems, it could and should move in the direction of addressing these issues.

The Federal government set up the Fiscal Pact in 1980, with a revision in 1993, promoted the decentralization of education and health in the 1990s, and at the end of that decade introduced an innovative and thus far successful regulatory system for subnational debt. Despite these important achievements, fiscal federalism has become a major headache for the national government. The national government struggled in the middle part of the last century to centralize taxation powers, and still sees benefits from that, but now also sees major problems in the spending authority and responsibility being much more decentralized than the revenue authority. Figure 1 shows the main sources and uses of revenues at the federal level; transfers to the subnational government take over 38 percent of the revenue, net of debt service. Since 1997 the presidential party has not controlled congress, which has therefore taken up the previously unused power to hold up the federal budget until its demands have been met. And each year those demands have included a large and growing allocation of transfers to the subnational governments. At first it was mainly a rationalization and unification in Ramo 33 of previously established transfers for sectoral programs, especially in health, education, and municipal infrastructure. These have grown, with some coordination for the federal executive, which has put them in the budget proposal each year since 1998. Beyond sectoral earmarking, which the federal government lacks the means to enforce but which anyway is non-binding in terms of sectoral allocations in each state (because the states also put substantial unearmarked funds into education and health), the federal authorities also lack any means to monitor how the states and municipalities are using the funds. Thus they do not know (but they want and need to know) whether the states are using those funds to achieve the goals that are part of the constitutional mandate for the federal government but which it has devolved to the states. Congress initiated another growing transfer, the Program for Strengthening Federal Entities (PAFEF), which has been expanded and reformulated each year, without its being in the executive's budget proposal. 
Figure 1. Main sources and uses of revenues at the federal level (2002)

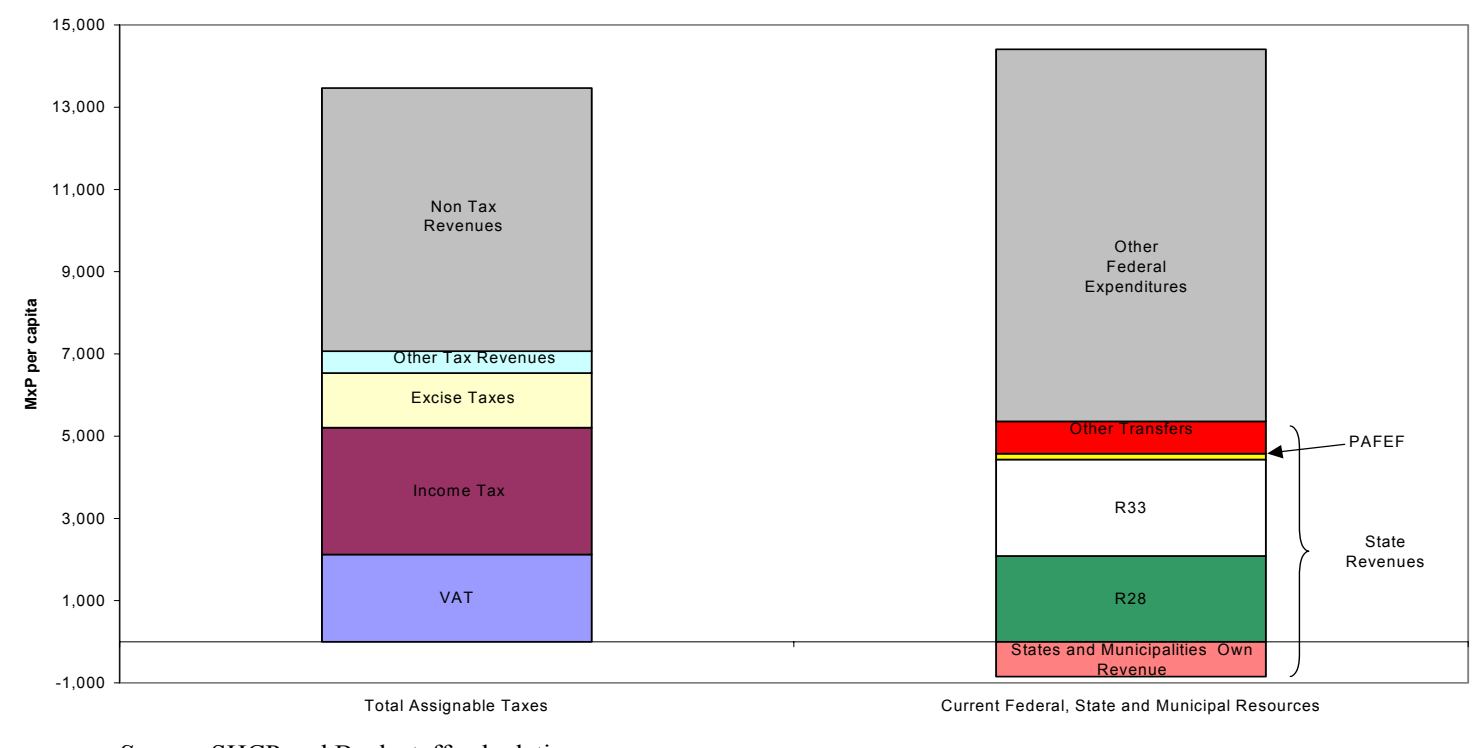

Source: SHCP and Bank staff calculations.

The negotiation process between the executive and congress also has several problems. First, there is not an effective set of rules for the interaction, especially on the issues of fiscal federalism. Second, congress does not have a good mechanism for making a binding agreement with the executive in budget matters, especially as the calendar moves toward December 31, at which point both sides know that the government will have to accept whatever congress passes. Consequently, the executive is reluctant to offer concessions that might then become the floor for further demands. It does seem that the Comisión de Hacienda y Crédito Público de la Cámara de Diputados is taking on the role of responsible interlocutor for budget negotiations, which would be a sound way to proceed. In 2002 the deliberation and passage of the 2003 budget went more smoothly than in the previous four years.

The federal executive has repeatedly agreed to expand sub national transfers, but it needs to have some limit on SN demands in congress. For this purpose, more SN fiscal effort would help, reversing a trend that has seen declining SN taxation as the transfers have increased. The federal government also needs to have assurances that national-level fiscal effort will benefit mainly the national-level fiscal balance. This is still true now, such as with the sub national governments getting only 20 percent in revenue sharing, but proposals to raise the participaciones share and to increase other transfers are undermining this situation.

To go along with its residual responsibility for public services devolved to the states (especially education, health, and roads), the federal government needs some way to monitor what the states are doing and to hold them accountable for the effectiveness of services that are still largely federally financed and are mandated by the federal constitution.

State governments lost almost all of their taxing powers in the series of measures up to and including the creation of the National System of Fiscal Coordination (SNCF) in 1980, but this gave them a secure source of revenue sharing, and they did not have much political autonomy or great spending responsibilities (except for the few larger states that developed their own large education systems to parallel the federal system). The 1990s changed their situation dramatically — giving them substantial new spending power and service-delivery responsibilities 
(mainly universal basic education and health for the uninsured), earmarked transfers for these sectors, and more effective political autonomy. The dependence of their revenues on federal transfers continued and is now out of step with their spending responsibilities, political autonomy, and freedom to borrow in the market. Also, the devolution of service responsibilities comes with a number of unfunded mandates from the federal level, particularly related to the pay and management of personnel. The states also want more transparency in the revenue sharing system and some protection against (excessive and arbitrary) reduction of transfers via administrative action during the budget year. (They believe this happened in 2002.)

All the states want more resources. Figure 2 shows the per capita distribution by type of transfer (and own revenue). ${ }^{3}$ The states are arrayed according to poverty levels; those having the highest rates of marginality (CONAPO) are on the left. While there is a lot of variation, on average the states with highest marginality get as much as the states in the middle and only a little less than the rich states on the right. Except for a couple of states like Tabasco and Campeche, which already get much more per capita than the others, the states do need more resources to meet their service obligations in the long run, although many of them lack the institutional capacity to use efficiently or effectively even the resources that they now are getting. Part of the problem is simple lack of technical capacity, but part is also in the centralized patron-client incentive structure associated with the transfers. With almost all resources coming from more or less automatic transfers, they are viewed as patronage to be distributed to employees and other clients, rather than as resources that the citizens pay for public services. To obtain more resources, at least some state governments want more ability and authority to raise own revenues. This would also have the benefit of shifting incentives toward encouraging accountability of the state governments for providing services to citizens in return for their tax payment.

The states are concerned about the horizontal dimension of the transfer and revenuesharing system (the distribution across states), as well as the vertical dimension between levels of government. A variety of state governments, from Nuevo Leon to Veracruz and Chiapas, have interest in more local tax authority, although the poorer states would also want some compensation for their lower tax base per capita, especially if the devolution of tax base to the states comes at the expense of the federal tax base and thus of the revenue shared with the states through the SNCF. Indeed, the states are asking for a reduction of federal rates to make tax room for the imposition of state taxes on the same bases. Most small states (and especially Tabasco) want long-run protection of the current level of transfers, since financially they are doing well in the system now. To make the devolution of taxes work, the states will need help with tax administration. For the institutionally stronger states, this would involve mainly provision of information about federal taxes collected in the state, particularly on the same bases as were devolved to the states. Other states will need more help, including institutional development and perhaps even federal collection of the tax on behalf of the state.

\footnotetext{
${ }^{3}$ The Ramo 25 resources for DF, which are spend by the federal government for basic education, are shown as aportaciones, to have comparability for all states. States own-revenue data is from 1998, adjusted for inflation; but not reflecting actual changes in local tax effort.
} 
Figure 2. State Government Resources -2002 distribution

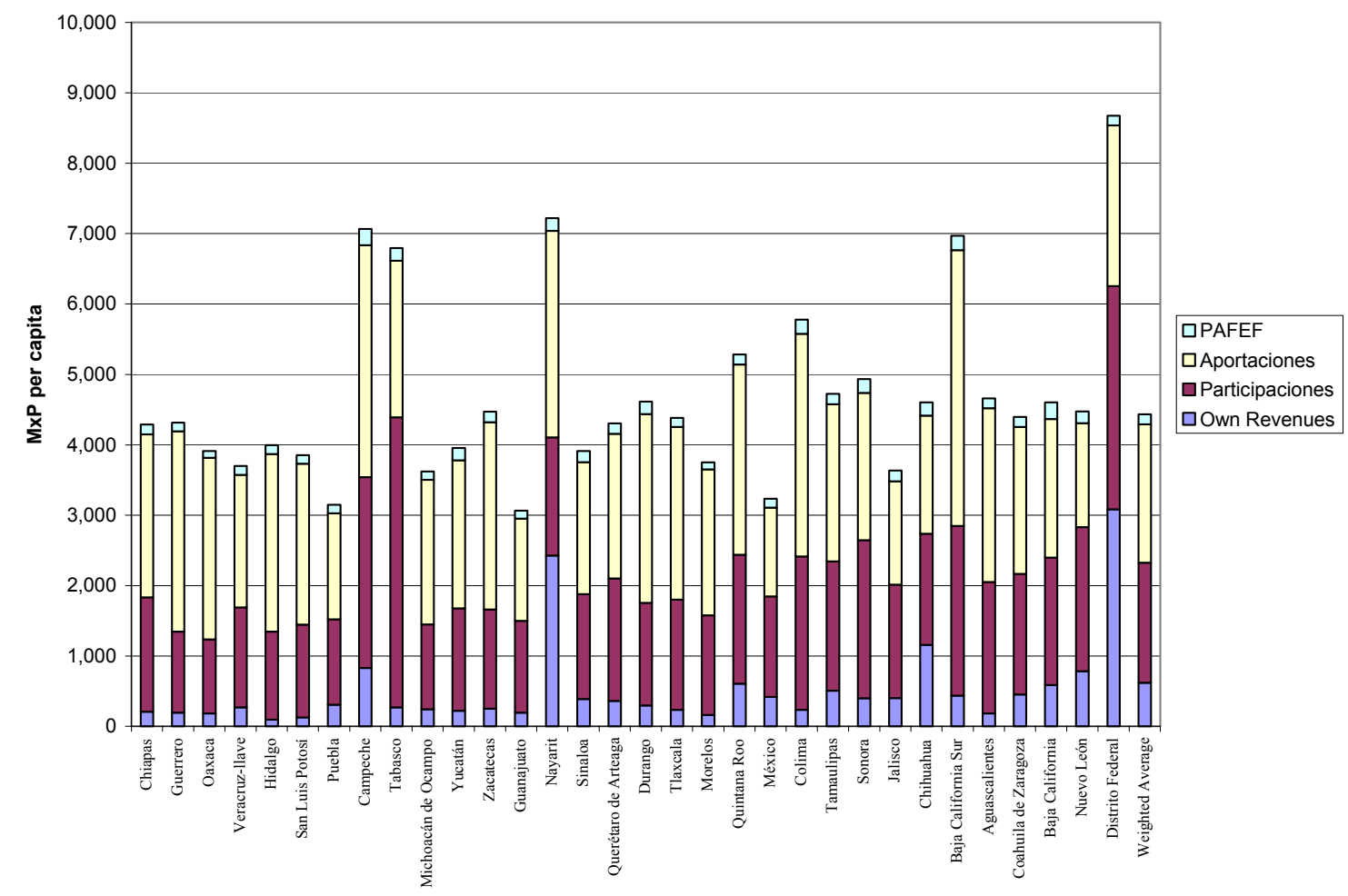

Source: SHCP and Bank staff calculations.

The aportaciones - transfers earmarked for education, health, social investment, and public security - amount to about half of all federal transfers and are the most unequally distributed. This is shown in figure 3 (the per capita distribution of each component of the aportaciones) and in the calculation of the coefficient of variation of per capita resources, which is 28 for aportaciones, and 32 for participaciones. ${ }^{4}$ The aportaciones are not correlated with poverty; they do not give more help to poorer states on average, nor less.

\footnotetext{
${ }^{4}$ The Ramo 25 resources for DF are considered FAEB.
} 
Figure 3. Aportaciones- 2002 Distribution (FAEB - basic education; FASSA - health; FISE state social investment; FISM - municipal social investment; FAM-education infrastructure and Progresa, FORTAMUN - municipalities, FAETA - technical and adult education, and FASP - public safety)

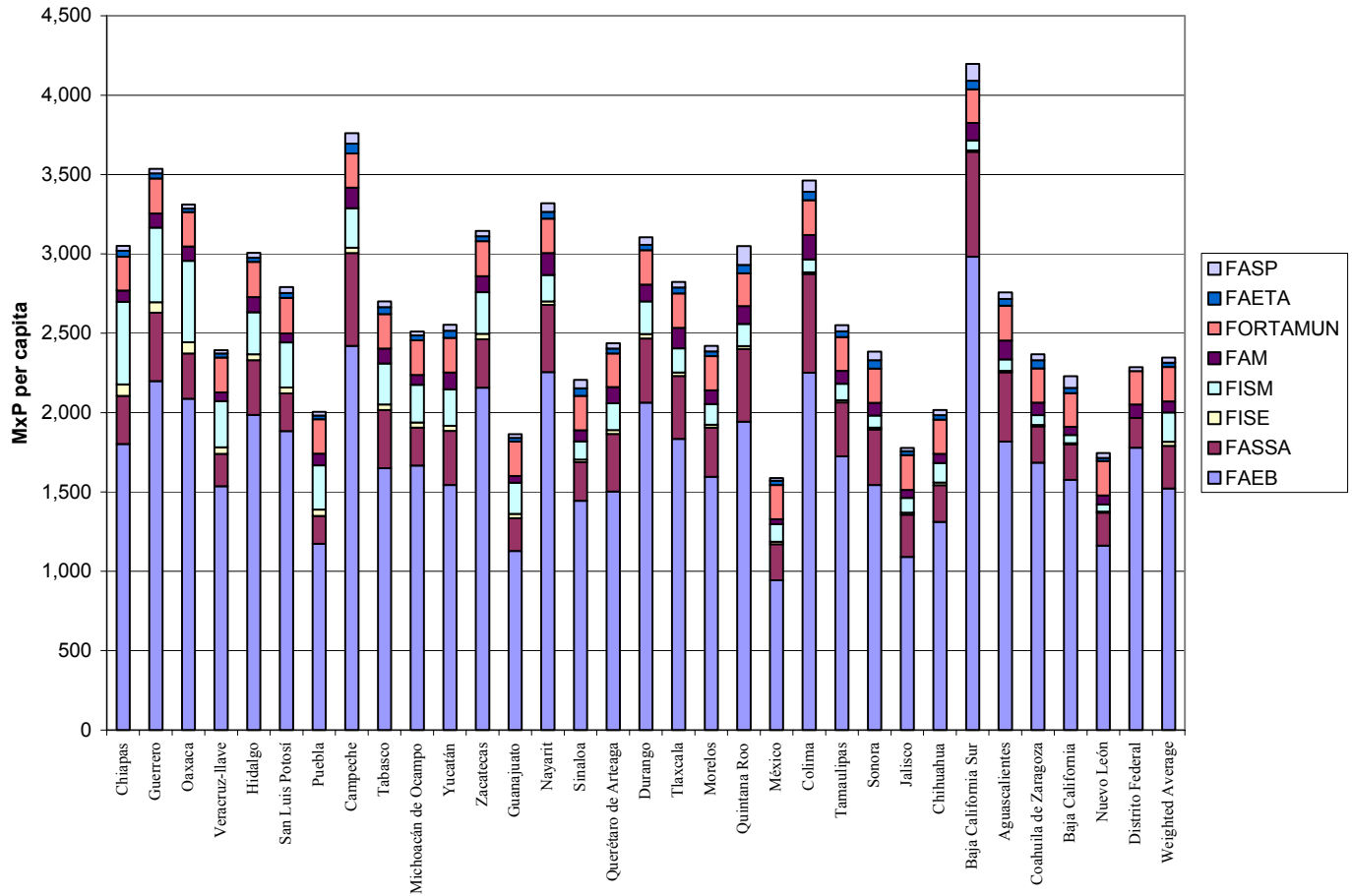

Source: SHCP and Bank staff calculations.

The majority of aportaciones to the states ( 75 percent) are for the basic education fund, which is allocated largely in line with the distribution of federal funding and federal teachers in 1993, when the federal education system was transferred over to the states. The states with the lowest aportaciones per capita_EdoMex, Guanajuato, and Puebla ${ }^{5}$ - ended up there because they had built up their own state-funded school systems before 1993 and therefore relied less on the federal system. These states continue to finance (with non-aportaciones resources) a large share of their basic education systems - up to one-half in EdoMex - even though these state governments are not rich in resources compared to the others. On the contrary, as figure 2 shows, they often have the lowest total resources as well as low aportaciones. The pattern of education transfers per school-age student is about the same as the transfer per capita (we lack the data to do a calculation on the basis of per student attendance).

In the health area, the picture is somewhat different. In contrast to education, where the vast majority of primary-school-age children attend public schools, now funded by or through the states, a large share of the population is on various health insurance plans instead of the state run program. What the states fund (mostly with aportaciones) and operate is the system for the "open" population, those outside the insurance system, mostly the poor. Figure 4 shows the

\footnotetext{
${ }^{5}$ The Federal District has the lowest level of Aportaciones in the country, because it does not receive any transfers for education and social infrastructure, given that the federal government directly provides these services in the District.
} 
distribution of Ramo 33 for health, in terms of pesos per person in the open system. In health, unlike education, one sees lower funding in the poorer states, because those have a larger share of their population in the open system.

Figure 4. Distribution of Ramo 33 for Health (2002)

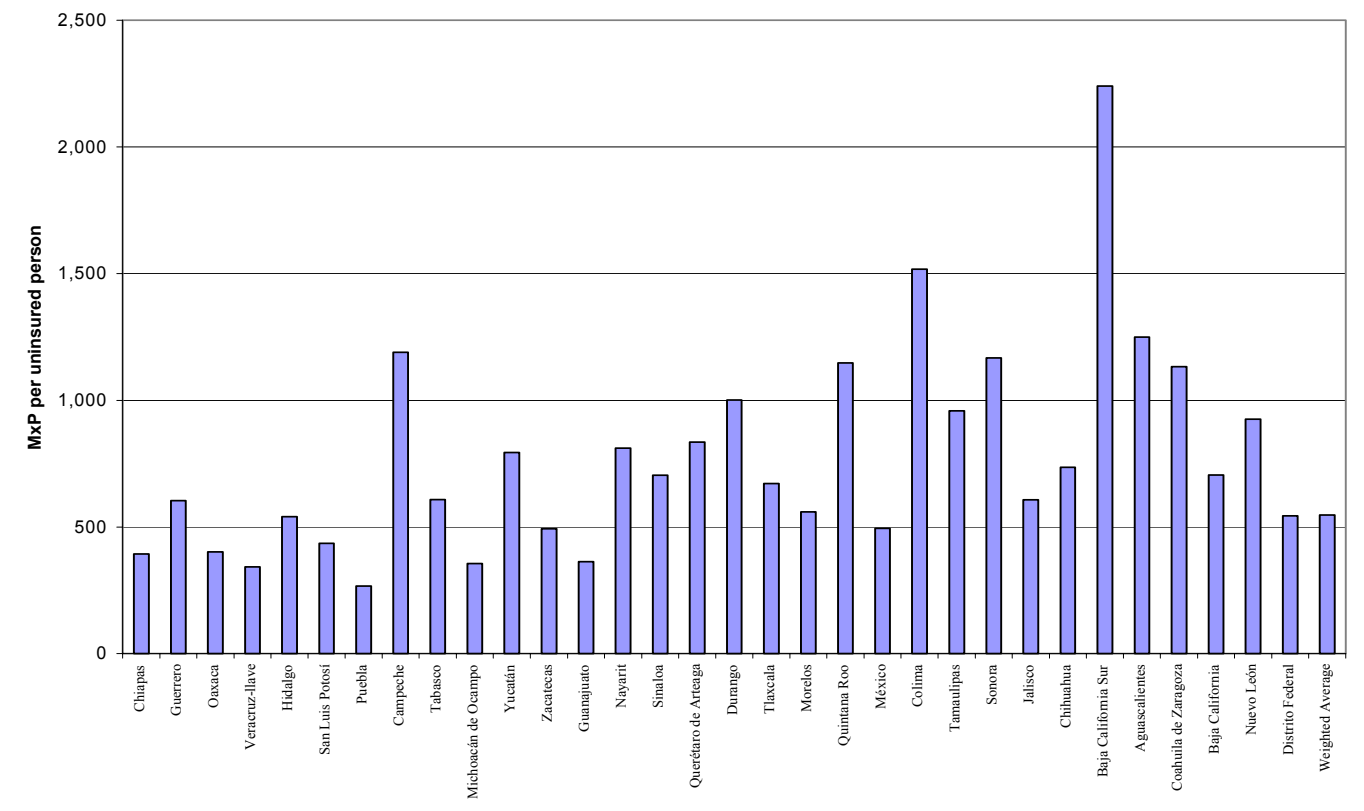

Source: SHCP and Bank staff calculations.

The states all want more effective control over resources received with aportaciones. This means particularly control of education and health personnel, although not necessarily the wage rate. This would allow the states to allocate personnel according to where the services are needed - on the basis of the number of students, school-aged children, patients in the open population, etc.- - and to hold the personnel, schools, clinics, and hospitals accountable for certain levels of service delivery and client satisfaction. Thus far the national unions (along with local unions and allies in some parts of the national and state governments) have opposed and usually blocked such changes.

The political dimensions of federalism are largely beyond the scope of this paper, but one aspect deserves mention for its special importance to fiscal management issues-that is, the (non)re-election of congressional delegates at both the state and federal levels. Not only are the three-year terms of deputies and mayors too short to plan ahead, but the no re-election rule means that once in office they have little incentive for loyalty to their state and locality, since their next job in the legislative or executive branch depends on connections within the party rather than the satisfaction of the constituents who elected them. The widely recognized benefits of change do not, however, guarantee that it will overcome resistance from traditional party interests that gain from the status quo.

Municipal governments in Mexico now seem to have the best of all worlds - good tax bases if they will use them (predial, water fees), relatively high transfers per capita (at least for small municipalities), and not an excessive burden of responsibilities. The federal and state transfers to municipalities are only loosely earmarked - for social infrastructure - and more importantly did not come with a powerfully unionized work force, as was the case for the states. 
Nonetheless, most municipalities need assistance to develop their capacity for planning and execution of programs. Figure 5 shows per capita transfer to municipalities as of 2001, and a projection of own revenues based on actual numbers collected by INEGI for 1999. Within each state there are also large variations in per capita allocations to municipalities. ${ }^{6}$ The largest municipalities have the property tax base, from which they can and occasionally do raise significant revenue, but the overall effect has been that their tax effort has declined since the municipal transfers were increased in Ramo 33 after 1997.

The municipal governments urgently need more capacity and time to plan for good use of the resources they receive. With mayors elected every three years and no chance for re-election, municipal governments lack the opportunity and incentive to do much that is meaningful - the same problem as for federal congressional deputies. Allowing re-election of mayors would benefit the cities greatly, enhancing the accountability of the mayors to the local populace and giving them time to plan something and, if the people like it and re-elect them, to implement it. A phase-in schedule similar to that for congressional deputies would make sense. ${ }^{7}$

Figure 5. Municipal Government Resources (2002)

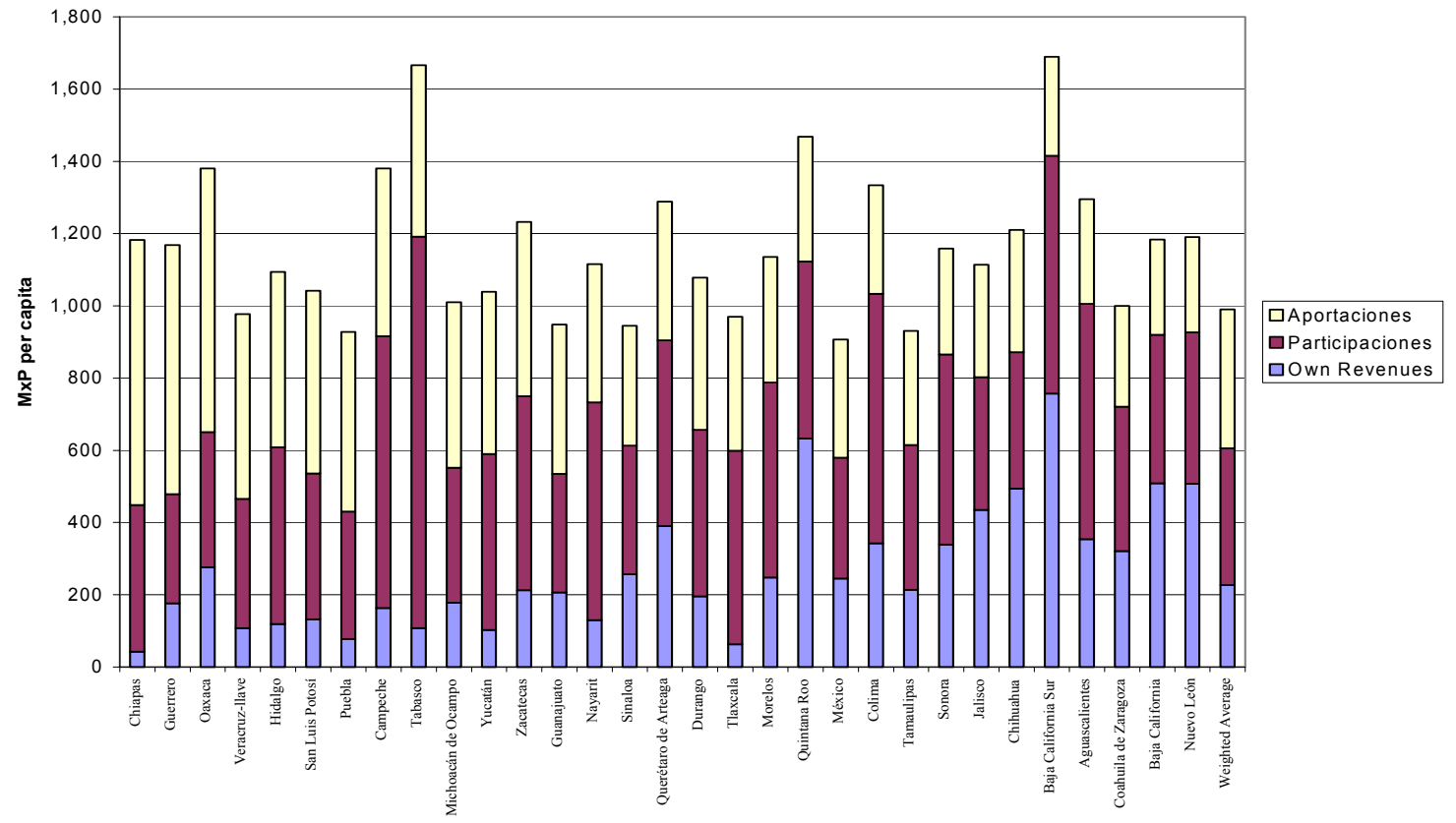

Source: SHCP and Bank staff calculations.

\section{Bargaining Packages}

For both economic rationality and political feasibility, it makes sense to think of packaging the reforms and bargaining along two main tracks - one concerning tax assignments, revenue sharing and tax administration, and another concerning the conjunction of earmarked transfers and accountability for service provision. Not coincidentally, the two main

\footnotetext{
${ }^{6}$ Appendix $\mathrm{C}$ shows some data and analysis of municipal transfers in two of the southern states.

${ }^{7}$ For instance, those elected in 2003 (or 2006) could be given the opportunity to run for a second term, and new deputies elected in say 2009 and thereafter could be allowed a maximum of three terms. Experience in other countries suggests the benefit of having some term limits.
} 
intergovernmental transfer programs, participaciones and aportaciones, are already set up in this way. In evaluating proposals, we can think of two standards. The minimum is that every state (or almost) is better off fiscally after the reform. The stronger standard, and perhaps also politically necessary, is that the post-reform system be consistent with the ethos that seems to be revealed in the present federal system - that even economically poor states get about the national average of resources per capita.

The overall Mexican constitution for the $21^{\text {st }}$ century-the written document plus the newly emerging pattern of political competition at all levels of government and frequent instances of party division between the executive and legislative branches in each entityrequires that various politically independent actors agree in order to make any changes and even some continuations of the status quo, as in the annual budget law. The existence of many noncompeting interests, and some shared interests, opens opportunities to deal with the competing interests in the context of packages. Indeed, there may be no other way for Mexican federalism to operate now. The real question is whether the packages will represent the lowest common denominator, leaving the parties better off only compared to a total collapse of the system, or whether the packages will make most parties substantially better off than before. Since the main points of conflict and dissatisfaction seem to be between the federal and state levels, we focus on bargains between them. Packages in two areas seem to have potential for making the federal government and almost all states ${ }^{8}$ better off in at least some important dimensions-one for reform of the SNCF (tax authority, tax rates, revenue sharing, and tax administration) and the other in Ramo 33 (aportaciones, accountability, control of spending, and security of funding for essential services).

Reform of SNCF. A core reform of the SNCF, or Fiscal Pact, would be for the federal government to give the states substantially more tax authority, even if it would never be enough to eliminate the need for some support from resources collected at the national level. Several other reforms would need to accompany such a devolution in order to make it feasible politically, fiscally, and administratively. The appropriate devolution of tax authority would be in a regular law (not annual revenue law) giving the states tax bases, such as the sales tax and a presumptive income tax on small entrepreneurships. The latter devolution was approved by Congress in December 2002, but not the sales tax, although it was seriously considered in 2001.

The revenue from the sales tax would vary widely across states, even when adjusted to a per capita basis. The simplest reasonable assumption is that revenue would be proportional to GDP, which yields a distribution as shown in Figure $6,{ }^{9}$ with the poorest states getting less than half of the national average per capita, and the best off getting almost twice as much (and the Federal District getting almost three times as much). Appendix A describes the method for these simulations.

\footnotetext{
${ }^{8}$ In any scenario where the federal government is better off and only one or two states lose, and we shall assume that the federal could pay a compensation to those potential loser states so that every entity becomes better off relative to the status quo.

${ }^{9}$ A potential problem by taking GDP as the basis for projecting the final sales tax collection is the distortion for the state of Campeche because its GDP accounts for all of the petroleum pumped from the Gulf of Mexico, and that will not lead to a final sales revenue in that state.
} 
Figure 6: Per Capita State Revenues from a 3 Percent Sales Tax

(states are arranged with the highest poverty rates on the left and lowest on the right, according to the CONAPO index of marginality).

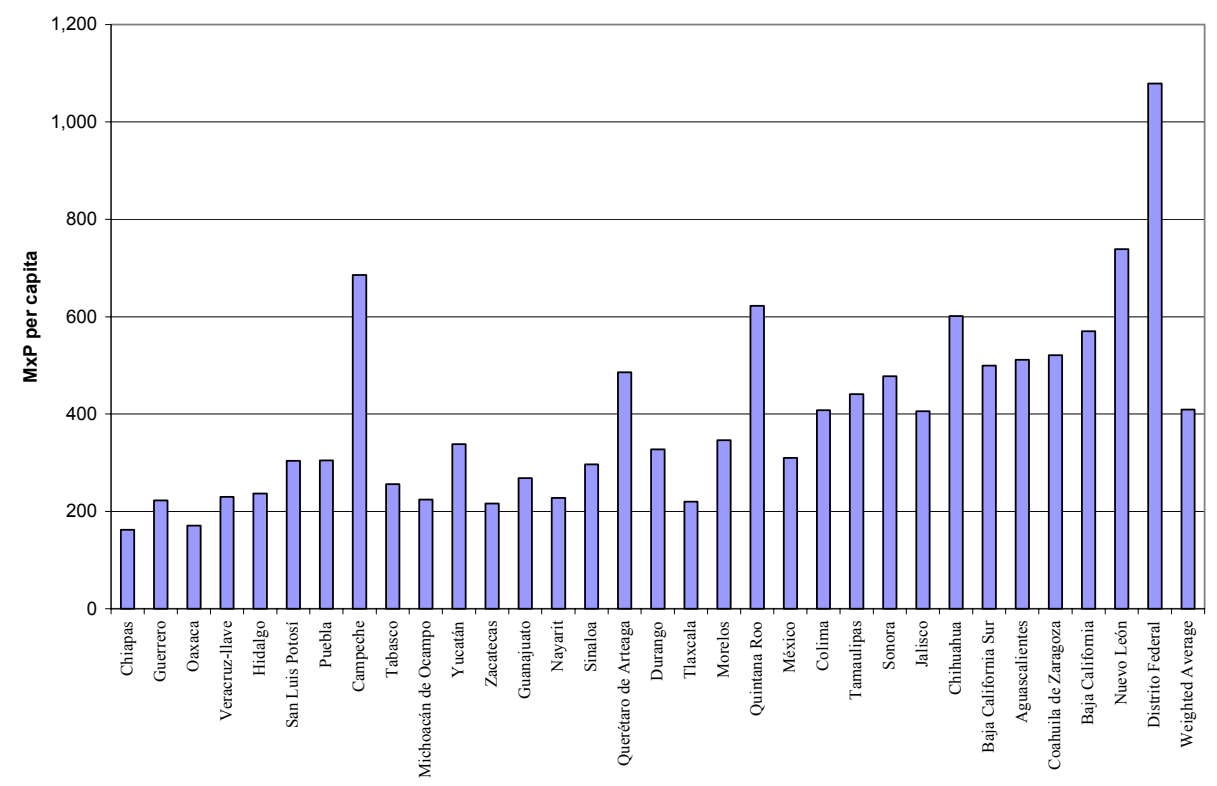

Source: Bank staff calculation.

To complement the authority to impose these taxes on the same bases as federal taxes, the states also want the federal government to reduce its rate somewhat, to create tax room. The concept of tax room relates to the general objective of keeping the total rate-state plus federal - at a politically tolerable level, and also to the practical administrative necessity of not driving taxpayers to shift the reporting of their income or sales to a different category where the state tax does not apply. In the VAT-sales tax area, even though regime switching would not be legal, putting a state sales tax on top of a uniform federal VAT (as in the proposal discussed in 2002) would give firms and their customers a clear incentive to under-report final sales and claim them as intermediate sales, thus avoiding the state tax. On the other hand, if the federal VAT on final sales were reduced by say 2 percent (as was discussed in 2001) and replaced with the state tax of 2 percent on final sales, then there would be little incentive for firms to misrepresent the nature of their sales. Reviving this approach might help passage of the state sales tax.

Who would pay for the creation of tax room? In 2001 the federal government wanted the states and municipalities to absorb all the loss from the VAT reduction (on final sales) through a reduction of their share in participaciones, to make the transaction revenue neutral for the federal government. And this demand contributed to the failure of the deal. The creation in 2001 of the special (optional) regime in the federal (corporate) income tax law with a lower rate for small payers (REPECO, gross annual revenue below MxP 1,570,000) did not come with any change in the participaciones formula (some think that its simplicity and lower rate will actually increase federal collections from this group), and so it faced no opposition from the states. Then in December 2002, Congress amended the Income Tax Law to give the states the authority to 
collect the tax revenues from the REPECO regime. The change also lowered the maximum rate and the number of tax brackets for this regime. Several states had indicated their willingness to impose the tax if it were in the regular law, but so far none has done so, perhaps because of the low revenue that has been collected in the REPECO thus far by the federal government. ${ }^{10}$

Does it matter if only some of the states use the new tax authority? A fundamental question for tax devolution is whether the tax policies of federal entities, which have considerable constitutional autonomy, should be coordinated, and how. The SNCF and its predecessor agreements came about partly in order to eliminate problems stemming from the lack of coordination, even state tax wars, that had plagued the federation. While the reforms that have been passed and are under discussion would still limit state discretion enough to avoid an all-out tax war, they will require some additional administrative measures. With the state level income tax in the small-payer regime, coordination is not a big issue, because the tax base of independent entrepreneurs is not very mobile between states, allowing each state to act independently, and the federal rate is now so low in that category that modest state taxes are unlikely to motivate many contributors to switch to other regimes (for middle-sized and large firms. Still, it will be important to assure that the small contributors actually file and pay in the state where they pursue there activity. With the sales tax, however, buyers could readily change the location of purchase of large items, to avoid paying the tax in any state that stood out as a high-rate state. ${ }^{11}$

Two important mechanisms for coordination for the sales tax would be the tax room that the federal gives to the states and the way the resulting reduction in General Fund for Sharable Revenue is passed on (or not) to the states in reduced transfers. Appendix B shows simulations of several possibilities. These results stand out:

- A devolution of the sales tax combined with a reduction in the federal VAT on final sales (this creation of tax room seems necessary to get the sales tax passed) will only be financially attractive to most of the sates if the federal government absorbs at least some of the cost of the reduced VAT.

- The transaction would still be attractive to all the states if the federal government absorbed only part of the cost. If the federal government absorbed half of the cost, it would need to compensate only Chiapas and Tabasco individually to have all states gain, as shown in the appendix.

- The municipalities would be affected by the reduction of the federal VAT and by any reduction in the share of federal revenues going to participaciones, therefore, the states could compensate them by sharing part of the sales tax revenue.

- Reducing the VAT on final sales only in the states choosing to impose the sales tax might work initially when only a few states participate. The rule for adjusting transfers would be more complex in this context.

\footnotetext{
${ }^{10}$ Revenue from the REPECO averaged only 10 pesos per capita in 2002 . In a few states it averaged over 20 pesos per capita, while in others it was only five pesos. Only if a state expected to improve revenue collection substantially (perhaps also by collecting other taxes and fees from firms that it identified with the collection of the REPECO), would it be worthwhile politically and fiscally to take on this tax.

${ }^{11}$ Requiring car (and boat) owners to register in their state of residence could allow states to require that residents who buy out of state still pay the tax, to reduce evasion by purchasing in a state with a lower rate. States in the US do this the sales tax, but it requires an administrative capacity that most Mexican states have not yet developed.
} 
Tax Administration. Both state and federal government would benefit from improved collaboration on tax administration, particularly with the new tax authorities being given (and considered) for the states. For both the sales tax and the tax on small contributors, the federal tax agency (SAT) should collect and provide to the states information on the taxable transactions in each state- that is, final sales and income reported in the federal small-payers regime (REPECO). For the sales tax, SAT would need to require firms to report sales, divided between sales to firms registered in the VAT system (non-final sales, subject only to the VAT) and other sales subject to the VAT and the sales tax. Nation-wide firms would need to keep track of the sales in each state and report that information to the SAT, which would share it with the corresponding states. On the other side of the information coordination process, the states would need to share back with SAT the information they gather in collecting the sales tax and their tax on firms in the REPECO regime.

Beyond this minimum level of assistance to the states, the federal government could actually collect the tax on behalf of the states, initially for free for all states and then for a small fee to cover costs and only for the states with less institutional capacity who chose to continue delegating their collection. In return, the states should (and would have natural incentives to) help enforce these taxes with inspections and audits. Chiapas, for instance, is already doing a street by street inventory of small business that they plan to use to help collect the income tax on small payers. States would also share with the federal government the information that they collect on each firm under these taxes, including the outcome of audits. The fundamental synergy would be the federal government helping states to collect from the big firms and the states helping the federal government to collect from the small firms.

Guarantees and Flexibility for Transfers. Since the states want more security about the size of transfers and the federal government wants to keep some flexibility in transfers to adjust to changing economic conditions, there needs to be a more transparent institution for meeting both desires. The participaciones are already theoretically fair in their adjustment to tax revenue changes, but the basic data on state-by-state tax collections needs to be published so that the process is more transparent. The government recently made the effects of oil price changes symmetrical, which would seem to take care of a distortion remaining in the revenue sharing system by giving states a full share of the upside of oil price fluctuations as well as the down side. With aportaciones and the PAFEF, the executive and congress (representing state interests) will need to formulate and institutionalize an agreement that establishes an affordable level of aportaciones plus PAFEF (based on a unbiased best estimate of revenue) with a rule by which these transfers to states would share in some but perhaps not all of the fluctuations in federal revenues during the year. ${ }^{12}$

Aportaciones and accountability. The devolution of new responsibilities to the states and municipalities in the early 1990s came with new transfers, the aportaciones, which were earmarked for those sectors, especially education and health at the state level. As discussed above, the states believe that they lack adequate authority to manage the programs, while the federal government sees a lack of accountability for performance. Increasing both the authority

\footnotetext{
${ }^{12}$ Agreeing on a macroeconomic forecast and the likelihood of deviations from it would be easier an less political if the Congress had more of its own capacity for economic analysis. Perhaps something like the beginning of a Congressional Budget Office could be established, attached to the Comisión de Hacienda y Crédito Público de la Cámara de Diputados. For a general discussion of the issue of how to safely accommodate the states desire for revenue security, see Gonzalez, Rosenblatt, and Webb, 2002.
} 
and accountability of the states could help improve the quality of services and citizen satisfaction. So, a good package would link the two. The question is: How?

Currently the federal government retains little authority in the social sectors other than to negotiate wages with the unions. For teachers, after national-level negotiations are finished every year, each state-level section of the union negotiates a second additional package of benefits with its state, and usually the state that gives the most concessions sets the national standard, since the union is more coordinated nationwide than the state governments. The states do not want to take over all the wage bargaining directly, but if a board of state secretaries of education participated in the national negotiations and set guidelines for the state-level ones, the outcomes might be more fair and sustainable. The states also want to gain control over other personnel issues, like assignment of positions to schools and of personnel to those positions, supervision and evaluation, and enforcement of accountability for parental and community satisfaction with the quality of service. At present the unions, led by the federal union in each sector, effectively hold this authority, which they inherited from their close political relationship with the PRI and formerly the federal government. Indeed, their power may have grown in the relative vacuum left when the federal government ended its direct control of the sectors. Unions have a valuable role to play in representing the interests of employees vis à vis management, but it is a perversion when the union takes over management and supervision, as is the case in many state-level social sectors. Working together the state and the federal governments could help solve this problem, although neither could do it alone. For instance, one part of the authorityaccountability package could be for the federal and state governments to make wage concessions to the union conditional on things like independent (non-union) supervision and assignment of teachers where the need is, as indicated by the residence of school-age children. Then the states and the teachers unions would have the incentive to work together to achieve such aims in ways that make a sustainable improvement in the quality and equity of service delivery.

While state accountability to the federal government has some attractions, along the lines of the German model, the Mexican federal government lacks the constitutional authority to demand that accountability, and the practical politics would be difficult if the states could call on local popular support to resist federal encroachment. On the other hand, the federal government could more likely enlist popular support if it made more effective delegation of authority to the states conditional upon state-level reforms to improve transparency and accountability to the local populace. To do this, the other part of the authority-accountability bargaining package could be for the federal government to make increased authority for the states (or perhaps increased transfers not earmarked for wages) conditional on actions like the publication of teacher attendance, monetary allocations, and school-by-school data on student performance. The last item would require establishment or improvement of standardized testing. ${ }^{13}$

Another key issue in the discussions of education and health decentralization is how Federal resources should be allocated among the various states and within states. Paqueo, Lopez-Acevedo and Parandekar (2003) shows that there are two approaches to this question for the education sector: "(a) bilateral negotiations between the Federal government and states with little transparency as to the rules; and (b) formula based distribution." The author finds that the former approach can led to allocation results that appear contrary to policy objectives like equity

\footnotetext{
${ }^{13}$ The state of Nuevo Leon now makes evaluations of each of its public schools available on the internet (educacion.nl.gob.mx), which illustrates the opening of possibilities and could serve as an example for other states.
} 
improvement and greater social inclusion in education. Paqueo, Lopez-Acevedo and Parandekar (2003) proposed three formulas based on per student allocation, ${ }^{14}$ and she found that any of these three approaches would improve not only efficiency but also equity.

For the health sector one should not analyze the allocation of the Fondo de Aportaciones para los Servicios de Salud (FASSA) in an isolated way, but rather one should also consider the resources of the health component of Oportunidades, Instituto Nacional Indigenista (INI), Programa de Ampliación de Cobertura (PAC), and the IMSS-Oportunidades. Figure 7 shows the allocation of these resources. With the exception of Campeche, it seems that richer states get more resources for their uninsured population than poor states. This trend, however, is driven by the shares of uninsured population in the states, where the richer states have the lowest shares and the poorest states the highest.

Figure 7: Federal Health Resources per uninsured person-2002 Distribution

(states are arranged with the highest poverty rates on the left and lowest on the right, according to the CONAPO index of marginality).

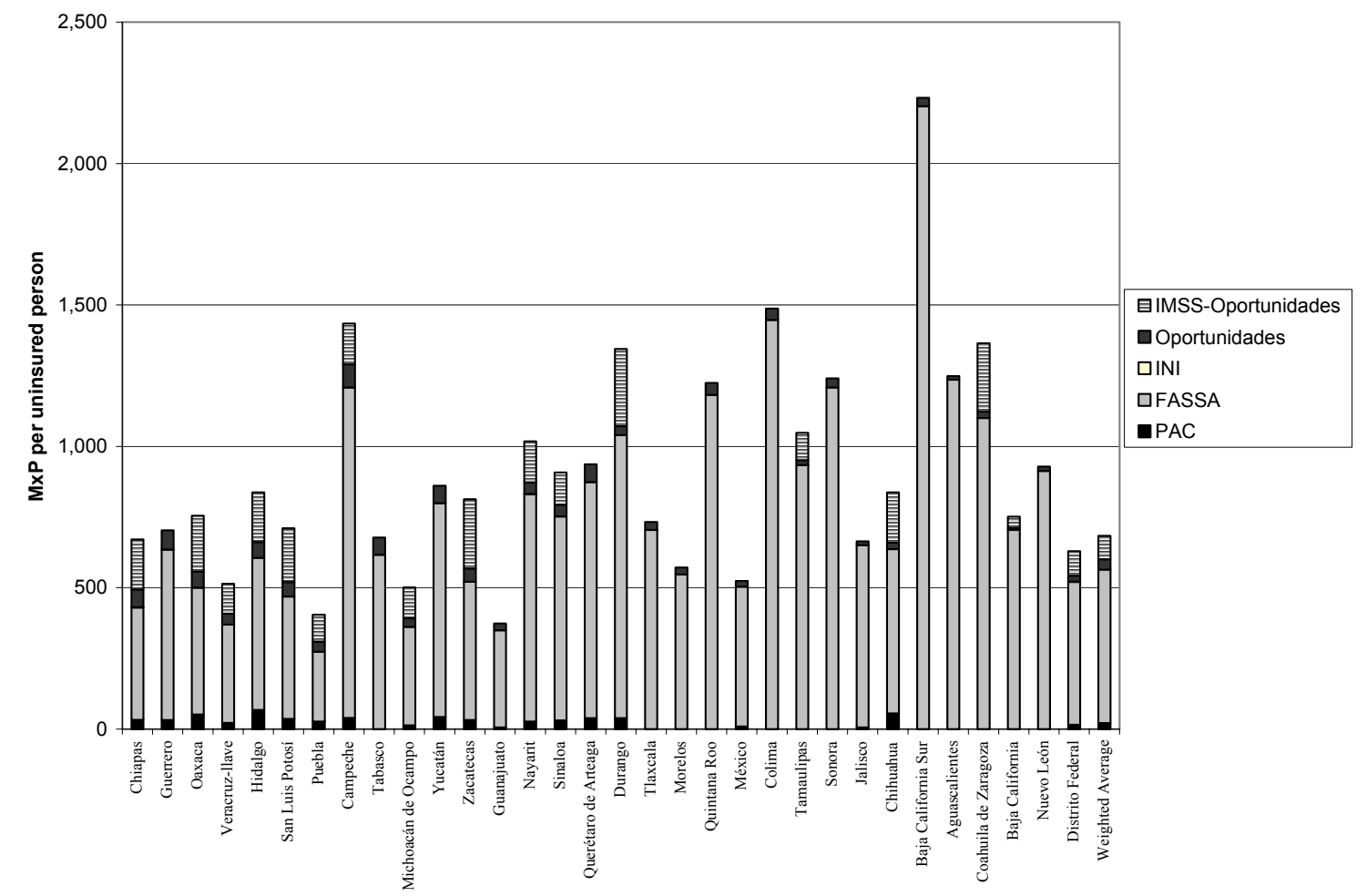

Source: SHCP and Bank staff calculations.

\footnotetext{
14 The three suggested formulas are: 1) uniform per student allocation, 2) productivity adjusted allocation, and 3) a multi-component formula based on the number of students and a supplementary component allocated according to the number of children in the state with special needs (rural, indigenous, or poor).
} 
Figure 8: Health Sector Expenditures Per Capita-2002 Distribution

(states are arranged with the highest poverty rates on the left and lowest on the right, according to the CONAPO index of marginality).

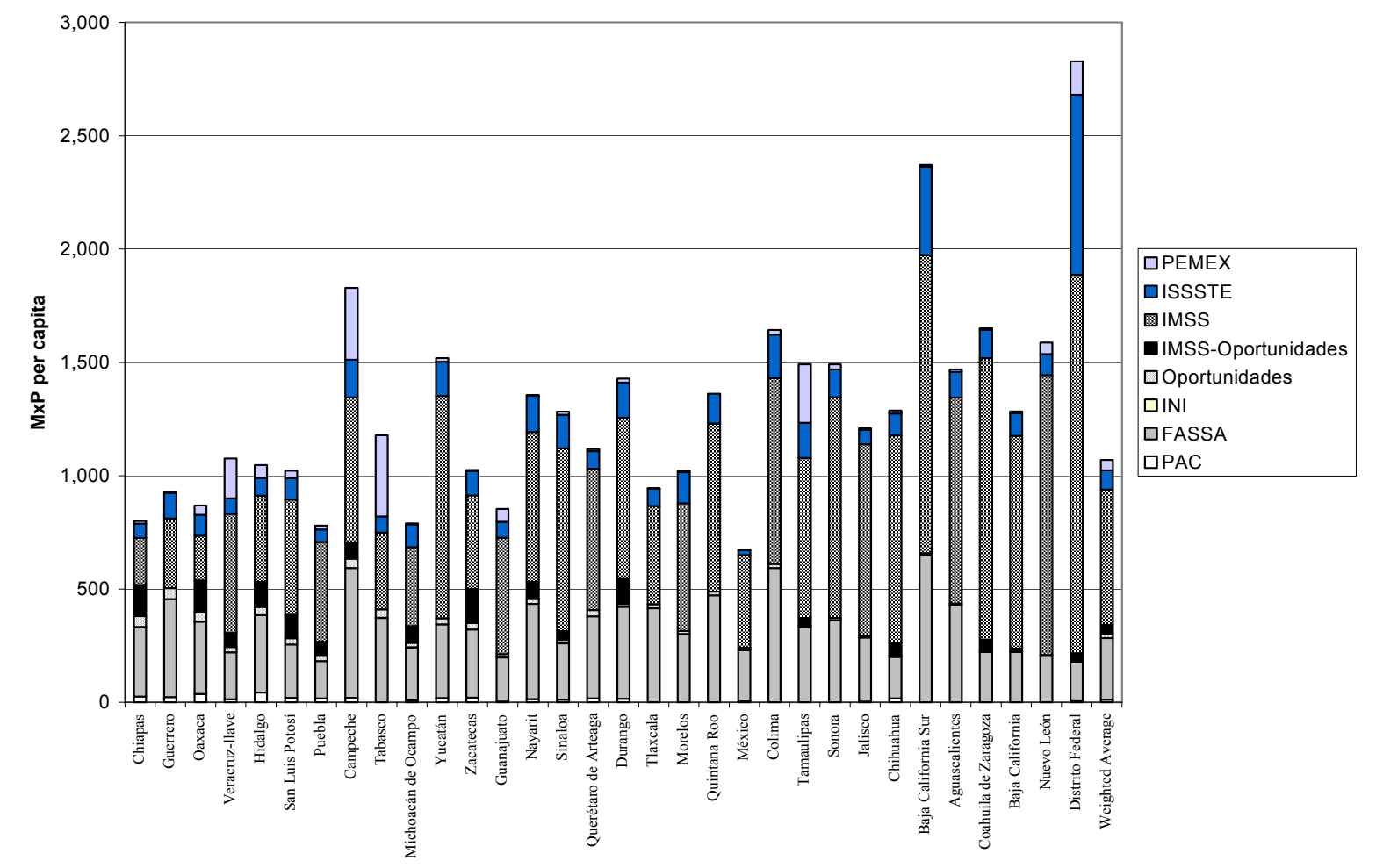

Source: SHCP and Bank staff calculations.

Considering all of the resources of the health sector, the federal transfers to the sector through FASSA help increase equality (See Figure 8), in the sense that its inclusion reduces the variance in the allocation of resources per capita. (The figure excludes the high outliers of the Federal District and Baja California Sur.) Still, better design of formulas could reduce inequality further.

PAFEF. Since 1998, Congress has been incorporating in the Presupuesto de Egresos the Programa de Apoyo para el Fortalecimiento de las Entidades Federativas (PAFEF) without any clear mechanism in the allocation of these resources across states. The initial purpose of PAFEF was to strength the education infrastructure in those states in which the state governments were not allocating enough resources. Therefore, these resources were earmarked for education infrastructure if the states did not allocate adequate resources for this; otherwise, they could use it for other type of infrastructure. In 2000, the rules changed, in such a way that a state could use it for infrastructure investment or for any problem the state had in their pension system. In 2002, Congress formalized this program, which now will be disbursed under Ramo 39, and modified its rules in such a way that states can use these resources for infrastructure and debt relief. The size of the program is relatively small, about 1.5 percent of Recaudación General Participable. One of the problems of this program is the lack of transparency or equality per capita in the allocation 
across states. If it is a politically necessary expedient, as appears to be the case, then its aggregate size should continue to be tightly limited.

\section{Recommendations}

To summarize, the following are the main recommendations for revising the participaciones/tax sharing system and the aportaciones/service devolution system.

\section{Taxes and revenue sharing}

- Increase resources for the states as a group via devolution of tax authority, rather than increases of aggregate transfers. Indeed, to the extent possible, reduce the aggregate transfers.

- Collect more state-by-state information on tax bases and actual collections, and share this with the states, along with other technical assistance as needed.

- Shift the formula for tax-sharing transfers, reducing the weight of historical factors and current revenue collection, and moving more toward a per capita basis or even to a redistribution toward states with below-average tax bases per capita. This would make the participaciones more strongly and more specifically a compensation mechanism, which should be politically possible and even necessary as the states get more tax authority, which would give the most benefit to states with good tax bases.

\section{Sectoral transfers and accountability}

- Increase the states' control over the use of aportaciones and their accountability to the local citizens and taxpayers.

- Shift the allocation of aportaciones toward a capitation basis, linked to the magnitude of the demand for services, rather than the size of the payroll for those supplying the services.

Getting to There from Here. In bargaining for the reform packages in each area, the federal government can take the lead role and it will be important to keep in mind the overall objectives as it bargains for each individual point.

Dimensions for productive concessions. The federal government could increase devolution of tax authority, in exchange for more accountability of SNGs for the use of that money. The devolution of tax authority is itself a fundamental measure to improve accountability of states to their taxpayers, which the federal government should emphasize. It can also increase transfers (or sustain them as federal tax rates are reduced to create tax room), but this option is limited by both fiscal constraints and the objective of shifting states' revenue dependence away from transfers and toward own revenue.

A tax reform of this magnitude, where the total pie to share expands dramatically, would offer an historic opportunity to revise the participaciones formula to promote equality, without requiring any state to take a reduction in its total fiscal resources. The revision of the formula seems to have two priorities: 
1. End or reduce the historical component, which has given a few states participaciones that are far out of line compared with the others. The component to reward tax effort with transfers could also be ended or reduced, because the devolution of the $\mathrm{VAT} / \mathrm{sales}$ tax would already reward states making tax effort.

2. Expand the equalization component to give explicitly additional participaciones to states with low tax bases.

If they accompany the expansion of the VAT base, these revisions could be done without making any state lose (or not much) relative to the status quo, and therefore it would be more feasible politically than a revision of the formula in isolation. Without expansion of the tax base, expanding the pie to be shared via devolution and transfers, no large reform of the participaciones formula seems possible, although marginal reforms, moving step-by-step in the desired direction, would be possible in combination with other reforms under consideration, such as the reform of aportaciones and the adjustment of participaciones in response to the reduction of federal rates to create tax room for devolution of taxes to states.

Unproductive dimensions for concessions. Simply increasing transfers to SNGs, in order to get the budget through, without any corresponding reforms or concessions from the states, weakens not only the fiscal strength and subsequent bargaining position of the federal government, but also its ability to act as a leader in the bargaining among the states.

Institutional obstacles. The main locus for changing laws pertaining to federalism is the federal congress. Neither the party leaders nor the state leaders (governors) have full control of their cohorts of deputies and senators. Building workable coalitions and ways to develop and enforce agreements will have to happen over time by trial and error, as the legislature and executive branches at the federal and state levels work through the reform of fiscal federalism and other such issues. Learning and building trust take time (for which re-election of deputies would help) and a broader sharing of understanding about the fiscal process. The increased openness of the fiscal accounts will help, as will the build-up of technical capacity in congressional staff. One might even envision the creation of the something equivalent to the U.S. Congressional Budget Office. The achievement of getting the 2003 annual revenue and spending laws passed in the first part of December 2002 was a positive step, moving away from the previous two years, when important decisions were forced at the last minute. 


\section{REFERENCES}

Giugale, Marcelo and Steven B. Webb, ed., (2000), Achievements and Challenges of Fiscal Decentralization, Lessons from Mexico. World Bank, Washington, DC

Gonzalez, Christian Y., David Rosenblatt, and Steven B. Webb (2002). Stabilizing Intergovernmental Transfers in Latin America: A Complement to National/Subnational Fiscal Rules? World Bank Policy Research Working Paper 2869, Washington, DC.

Paqueo, Vicente, Gladys Lopez-Acevedo and Suhas Parandekar (2003), On the Use of Transparent Formulas to Allocate Federal Education Transfers. World Bank Working Paper 3171, Washington, DC.

Webb, Steven B. (2001), "Decentralization" in Giugale, Lafourcade, and Nguyen, ed., Mexico: $A$ Comprehensive Development Agenda for the New Era, Washington, DC: World Bank.

Winkler, Donald and Alec Ian Gershberg (2000), "Education Decentralization in Latin America: The Effects of the Quality of Schooling," in Burki and Perry, et al, ed., Decentralization and Accountability of the Public Sector in Latin America, Proceedings of the Annual World Bank Conference on Development in Latin America and the Caribbean 1999. World Bank, Washington, DC. 


\section{Appendix A}

\section{Figures and Simulations}

For Figure 2, raw data for Aportaciones and Participaciones were taken from the Statistical Annex of the 2002 President's Report. Data on PAFEF was taken from the Presupuesto de Egresos 2001. Marginality index and population were obtained from CONAPO. State own revenues was obtained from INEGI. Finally, the Fondo de Fomento Municipal and state own revenues were obtained from SHCP. To estimate the participaciones going to each state, we subtracted the Fondo de Fomento Municipal from the Participaciones, then we multiply this amount by 0.8 . And, for the Aportaciones, there are only two funds that go to the municipalities, FORTAMUN and FISM, so we subtract them from the total aportaciones.

For Figure 5, we use the same data from Figure 4. To estimate the participaciones going to each state, we subtracted the Fondo de Fomento Municipal from the Participaciones, then we multiply this amount by 0.2 and then add the Fondo de Fomento Municipal again. Municipal own revenues was obtained from INEGI. And, for the Aportaciones, there are only two funds that go to the municipalities, FORTAMUN and FISM, so we simply add these two funds together.

For Figure 6, we took one fifth of the VAT 2001 collection and distributed according to GDP. That is, we obtained the shares of GDP produced by each state and multiply by one fifth of the VAT 2001 collection.

For Figures 9 through 12, the first part was to obtained the sales tax revenue collection. For that, we multiplied the VAT 2001 collection by $2 / 15$ and distributed to states according to GDP. Then, we estimated the total loss to the federal government if they absorb all the cost of the reform by multiplying the total sales tax revenue by 0.8 , because around 20 percent of the VAT revenue is shared with the states and municipalities. This amount was reduced from the participaciones in the different scenarios $(0 \%, 50 \%, 100 \%$ of the cost is absorbed by the states and municipalities). That is, the loss was subtracted from the total amount of the participaciones, and then we distributed it across states based upon the 2001 share that they received. 


\section{Appendix B}

\section{Dynamics of States' Choice for the Retail Sales Tax}

As an initial illustrative example, we assume only 2 states, A and B, with A having higher per capita income and therefore proportionately higher (potential) per capita revenue from a sales tax. Participaciones are assumed to be distributed equally per capita, although this now applies to less than half of them under the actual rules. We assume that the states would put on a 2 percent tax on final sales. We also assume that the effective tax base is the same for all setups, although in practice we know that the rules matter here. ${ }^{15}$

\section{Table A-1: Two-State simulations of Tax Devolution with Tax Room}

\begin{tabular}{|c|c|c|c|c|}
\hline & State A & State B & Federal & total \\
\hline population & 1 & 1 & 2 & \\
\hline $\mathrm{GDP}=$ income & $\$ 200$ & $\$ 100$ & $\$ 300$ & \\
\hline \multicolumn{5}{|l|}{ Initial Status } \\
\hline Federal tax rate & & & 0.15 & \\
\hline Federal tax revenue, by location & $\$ 30.00$ & $\$ 15.00$ & $\$ 45.00$ & \\
\hline participaciones share in FGP & & & 0.2 & \\
\hline revenue sharing — equal per capita & $\$ 4.50$ & $\$ 4.50$ & & \\
\hline Total net revenue & $\$ 4.50$ & $\$ 4.50$ & $\$ 36.00$ & $\$ 45.00$ \\
\hline \multicolumn{5}{|c|}{ Model I -- tax room and revenue neutrality } \\
\hline state rate & 0.02 & 0.02 & & \\
\hline own revenue & $\$ 4.00$ & $\$ 2.00$ & & \\
\hline Federal tax rate & & & 0.13 & \\
\hline Federal tax revenue, by location & $\$ 26.00$ & $\$ 13.00$ & $\$ 39.00$ & 0.17 \\
\hline Participaciones share in FGP & & & 0.076923 & \\
\hline revenue sharing & $\$ 1.50$ & $\$ 1.50$ & & \\
\hline Total net revenue & $\$ 5.50$ & $\$ 3.50$ & $\$ 36.00$ & $\$ 45.00$ \\
\hline \multicolumn{5}{|c|}{ Model II -- tax room, fully paid by federal } \\
\hline state rate & 0.02 & 0.02 & & \\
\hline own revenue & $\$ 4.00$ & $\$ 2.00$ & & \\
\hline Federal tax rate & & & 0.13 & \\
\hline Federal tax revenue, by location & $\$ 26.00$ & $\$ 13.00$ & $\$ 39.00$ & 0.20 \\
\hline participaciones share in FGP & & & 0.230769 & \\
\hline revenue sharing & $\$ 4.50$ & $\$ 4.50$ & & \\
\hline Total net revenue & $\$ 8.50$ & $\$ 6.50$ & $\$ 30.00$ & $\$ 45.00$ \\
\hline \multicolumn{5}{|c|}{ Model III -- tax room, half paid by federal } \\
\hline state rate & 0.02 & 0.02 & & \\
\hline own revenue & $\$ 4.00$ & $\$ 2.00$ & & \\
\hline Federal tax rate & & & 0.13 & \\
\hline Federal tax rev & $\$ 26.00$ & $\$ 13.00$ & $\$ 39.00$ & 0.20 \\
\hline participaciones share in FGP & & & 0.153846 & \\
\hline revenue sharing & $\$ 3.00$ & $\$ 3.00$ & & \\
\hline Total net revenue & $\$ 7.00$ & $\$ 5.00$ & $\$ 33.00$ & $\$ 45.00$ \\
\hline
\end{tabular}

${ }^{15}$ The VAT and sales tax are the only taxes here, in contrast to the VAT being only about one-third of total revenue going into the General Sharable Fund in Mexico today. Thus the simulations exaggerate the effects of changing the rules for VAT and sales taxes, and thus illustrate the issues more clearly. 
The federal VAT on final sales is reduced by 2 percent to create tax room for the state tax, to avoid stimulating (more) evasion, and public outcry. The variable parameter then is the extent to which the federal government pays for this, or make the states pay. In Model I, the federal government reduces participaciones enough to cover the full cost of reducing its VAT rate. Then the states as a group also get the same total revenue (transfer plus own revenue), but the rich state A gains, and state B loses substantially relative to the status quo. When participaciones stay the same, and the federal government absorbs all the cost of creating tax room with reduction of the VAT - Model II - then both the rich and the poor states gain, but it is very costly to the federal government. When the federal government absorbs half of the cost of the reduced VAT-Model III-both states gain still, although A gains more, and the federal government loses less than one tenth of its VAT revenue.

Analogous simulations with the full variety of Mexican states show similar results; the deviations of the current participaciones formula away from equal per capita make the outcomes more complex. With the federal government absorbing all the cost of reducing the VAT to make tax room, all states gain of course, as shown in Figure 9. If the federal government passes all the cost of reduced VAT on to the states, then only ten states gain, especially the DF, Nuevo Leon, and Chihuahua, as shown in Figure 10. With the federal government absorbing half of the cost, however, only two states lose, as shown in figures 11 and 12 . Even with the cost of individually compensating these two, a shared cost like this would be much more affordable for the federal government than bearing the full cost of the reduced VAT, and would be much more politically feasible than trying to pass all the cost on to the states.

Figure 9. Net gain when Federal Government cuts VAT rate to 13\%, and states impose a 2\% Final Sales Tax

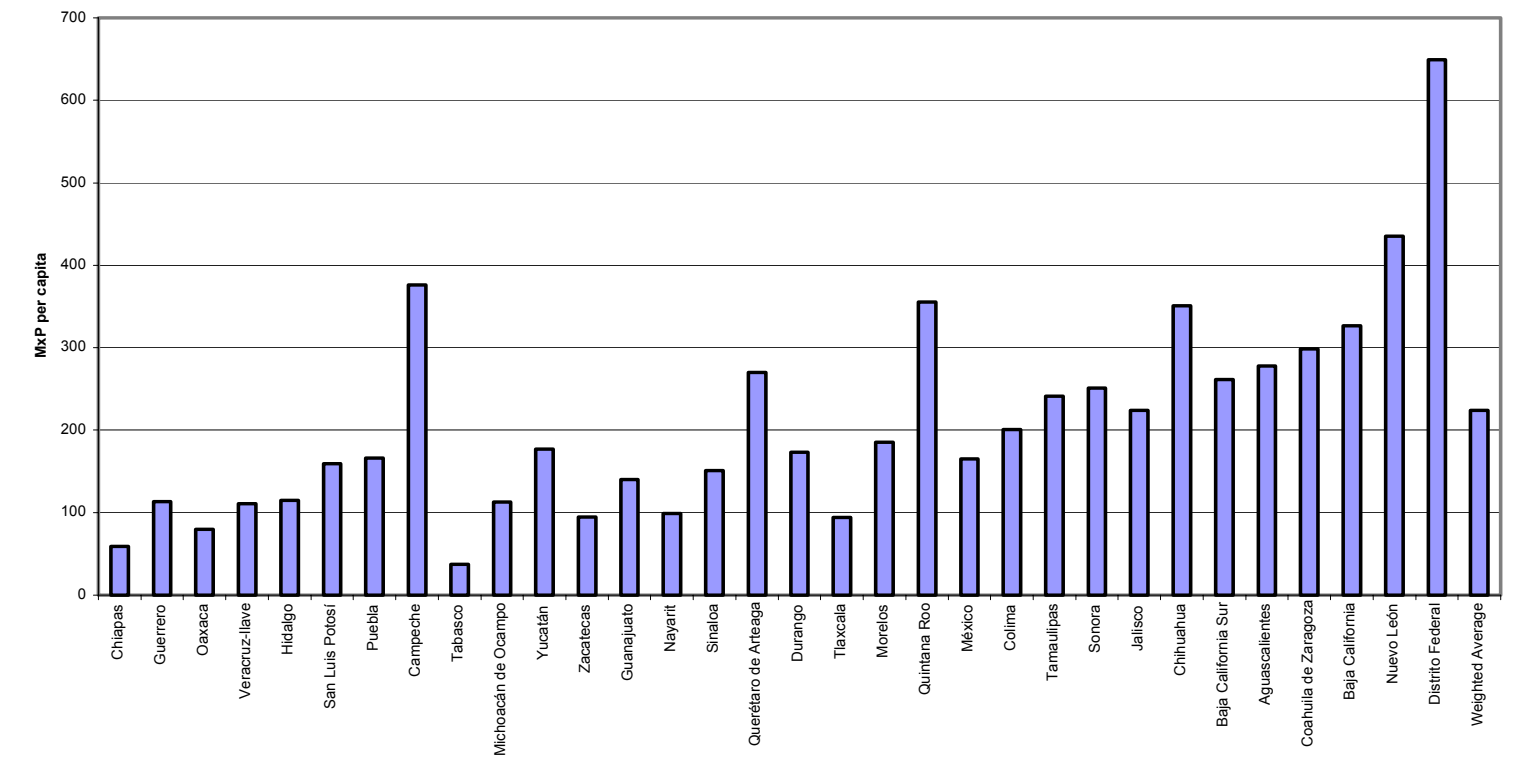

Source: Bank staff calculations. 
Figure 10. Net Gain when federal government cuts VAT rate to $13 \%$ and passes a $100 \%$ of the cost to the states, and States impose a 2\% Final Sales Tax

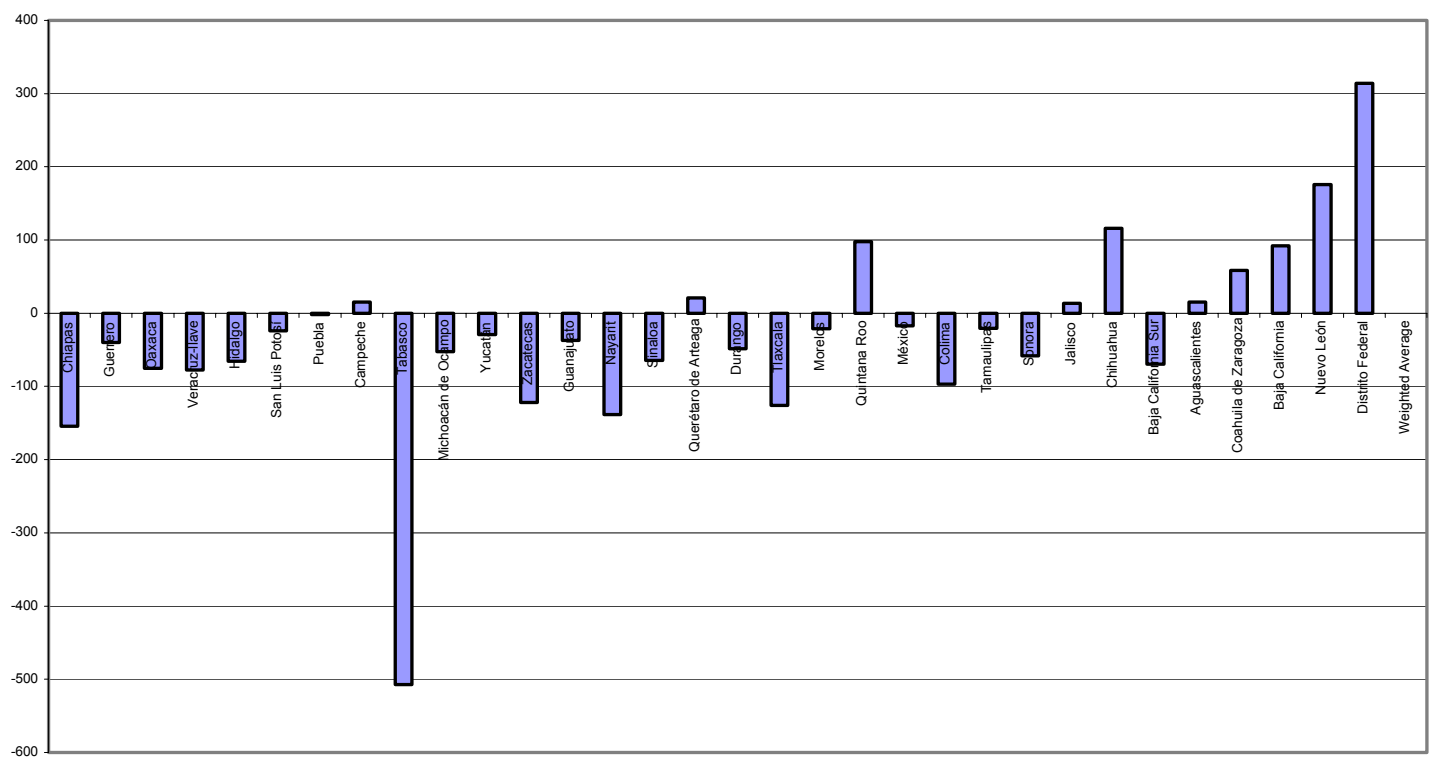

Source: Bank staff calculations.

Figure 11. Federal Government cuts VAT rate to $13 \%$ and passes along $50 \%$ of the total cost to the states, and States impose a 2\% Final Sales Tax

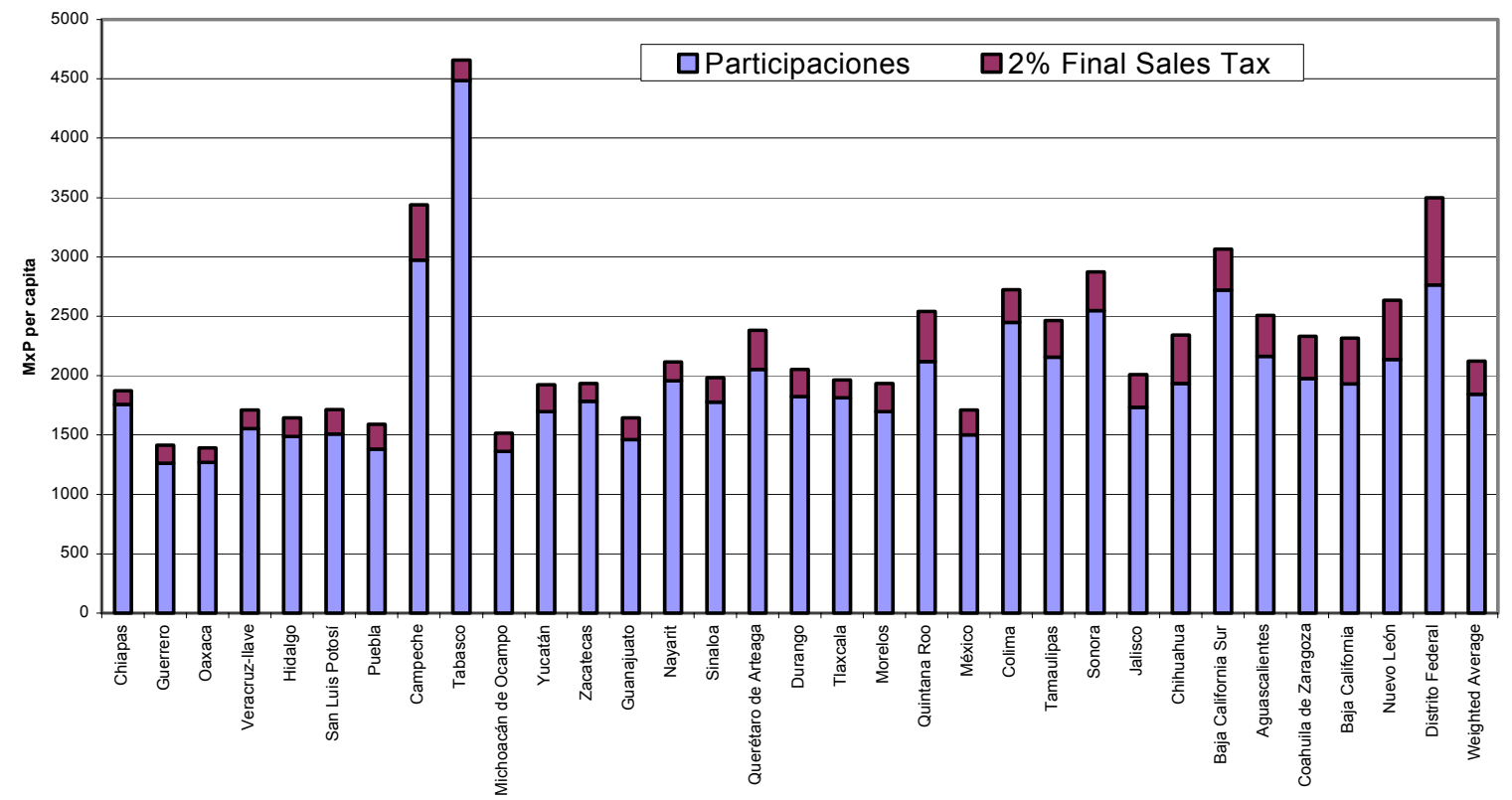

Source: Bank staff calculations. 
Figure 12. Net gain when federal government cuts VAT rate to $13 \%$ and passes along $50 \%$ of the total cost to the states, and States impose a 2\% Final Sales Tax

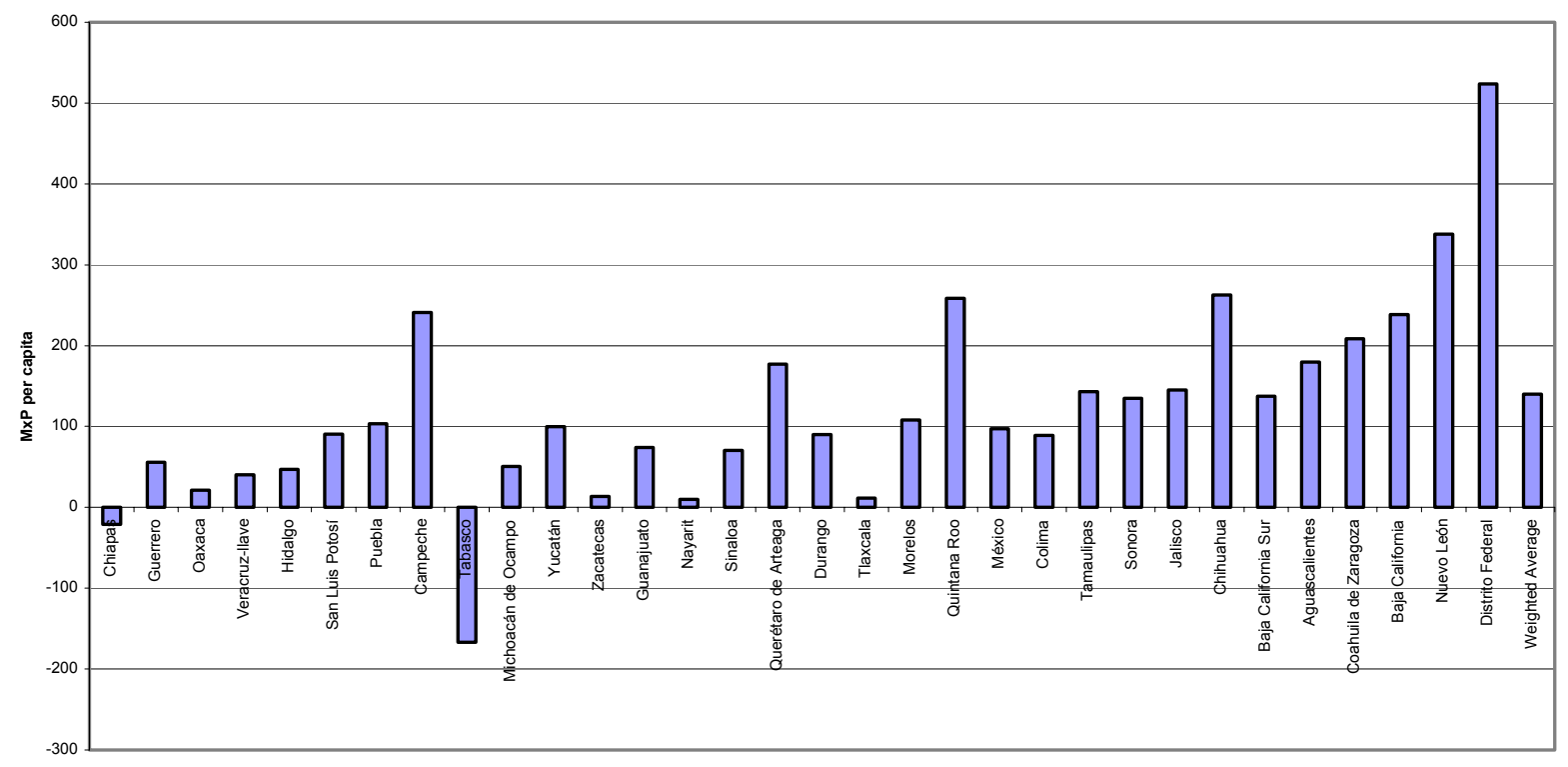

Source: Bank staff calculations.

\section{Appendix C}

\section{Analysis of municipal transfers in Chiapas and Guerrero}

Partcipaciones are unconditional federal transfers which are allocated among states, according to a formula established in the Ley de Coordinación Fiscal. States distribute 20 percent of these funds to municipalities following a formula similar to the one used by the Federal Government, that is, partly per capita, partly rewarding local tax effort, and partly to the (small and poor) municipalities that do poorly on the other two measures. Comparing the participaciones going to each municipality in the southern states - Chiapas and Guerrero, one does not see the poorer (or the less poor) municipalities getting systematically less than the average, although there is a lot of variation around the average that is not correlated with the marginality index. 
Figure 13. Participaciones To Municipalities in Chiapas

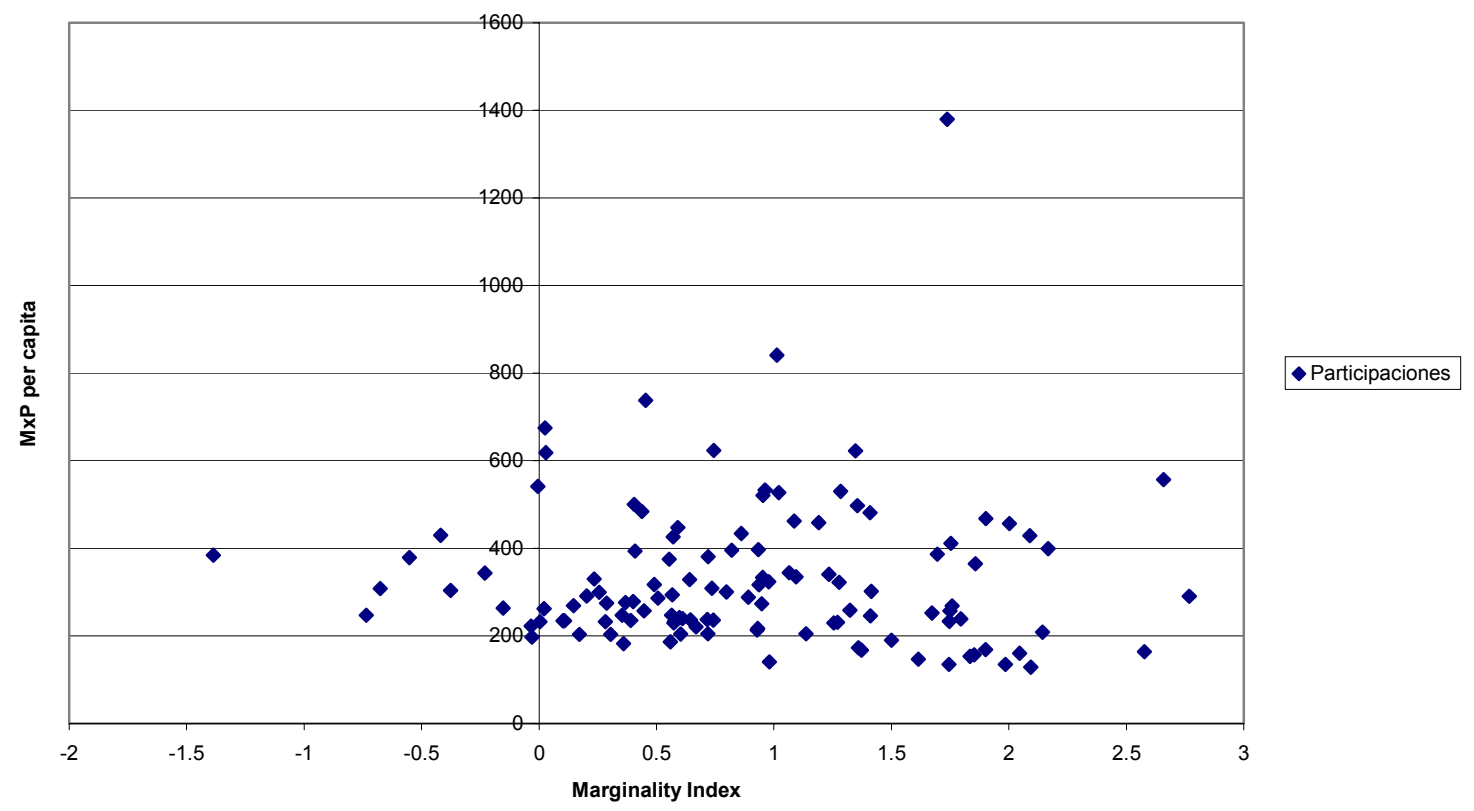

Source: Bank staff calculations.

Figure 14. Participaciones To Municipalities in Guerrero

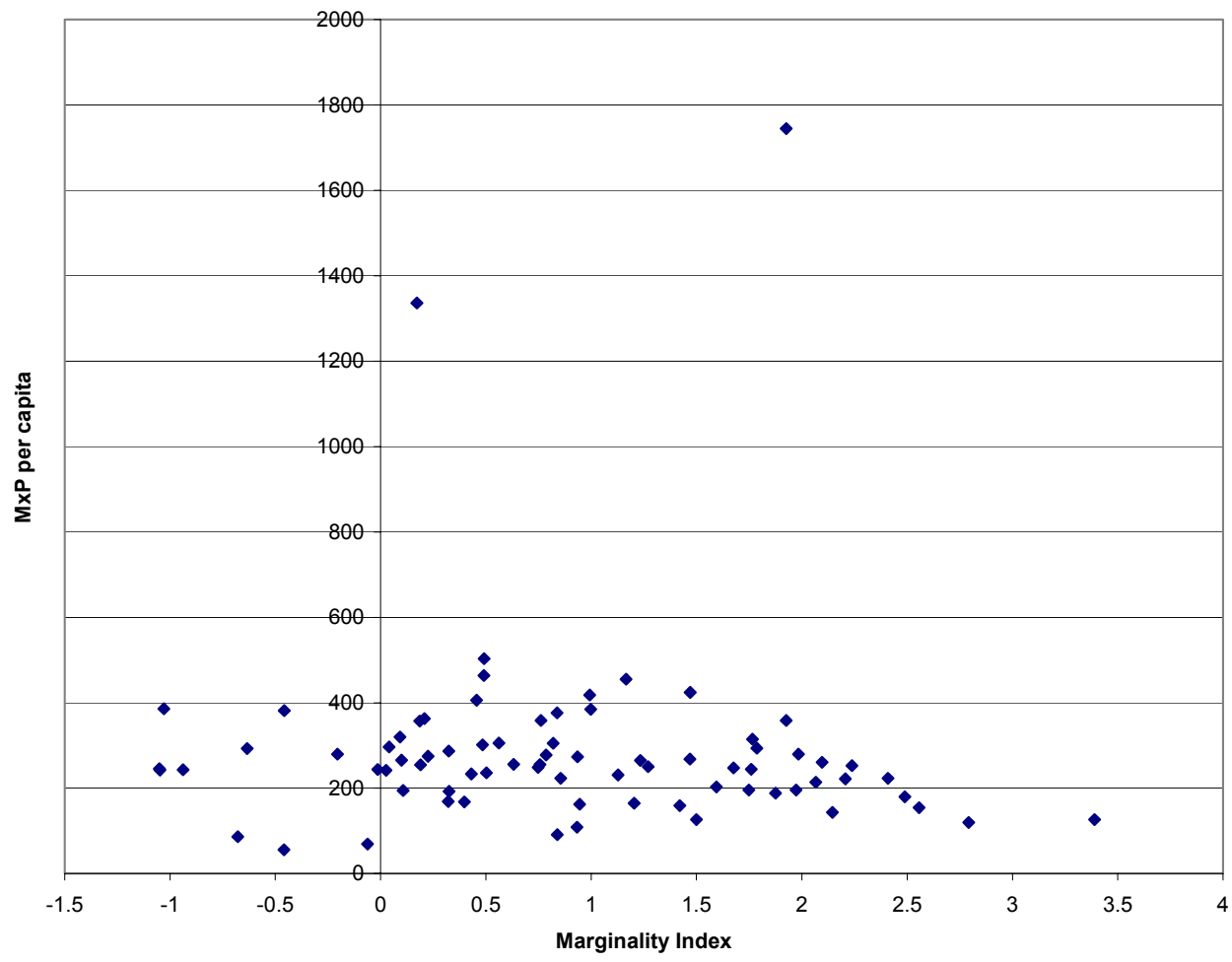

Source: Bank staff calculations. 
Aportaciones are earmarked federal transfers. Two of the 9 funds that compromise the Aportaciones are distributed at the municipal level: Fondo de Infraestructura Social Municipal (FISM) and Fondo para el Fortalecimiento Municipal (FORTAMUN). The allocation from the federal to state governments of the FISM is done according to a formula. The FORTAMUN is distributed across states at the discretion of Federal Congress and executive, although the distribution changes little from year to year. The states redistribute the FISM funds to the municipalities according to a formula similar to the federal one for distribution across states - a formula that gives more to places with higher marginality and poverty. The formula also gives a certain amount to each municipality regardless of size, which substantially increases the amount per capita in small municipalities but means nothing to the large ones. The resources of FORTAMUN, on the other hand, are distributed among municipalities at the discretion of the state government, mirroring the discretionality at the federal level.

Although earmarked for municipal investment, neither fund of aportaciones for municipalities has tight earmarking or a constituency with a prior claim to the resources (in contrast to the education and health transfers at the state level), so the municipalities have relatively free disposition of these resources.

Figure 15. Aportaciones To Municipalities Chiapas

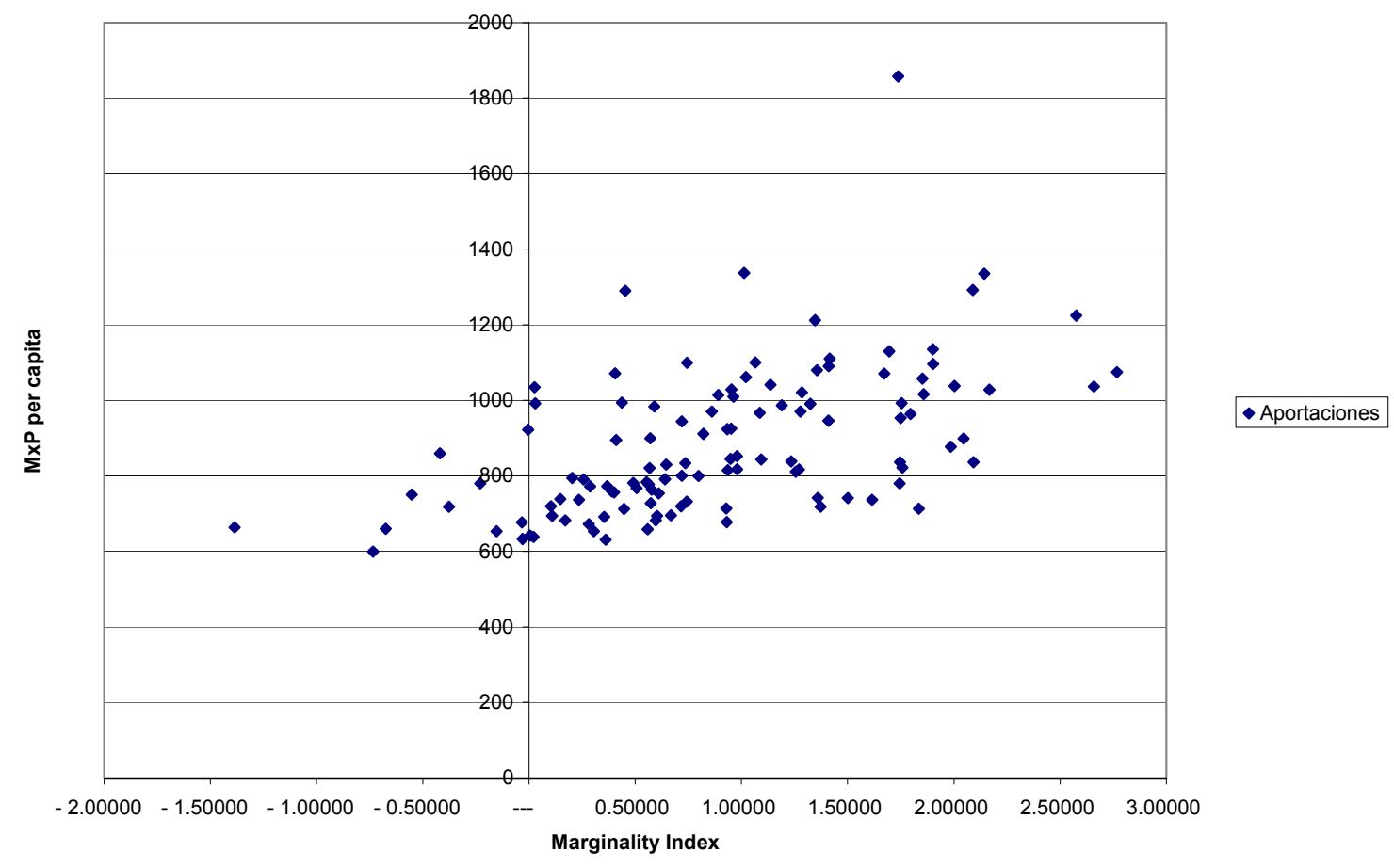

Source: Bank staff calculations. 
Figure 16. Aportaciones To Municipalities in Guerrero

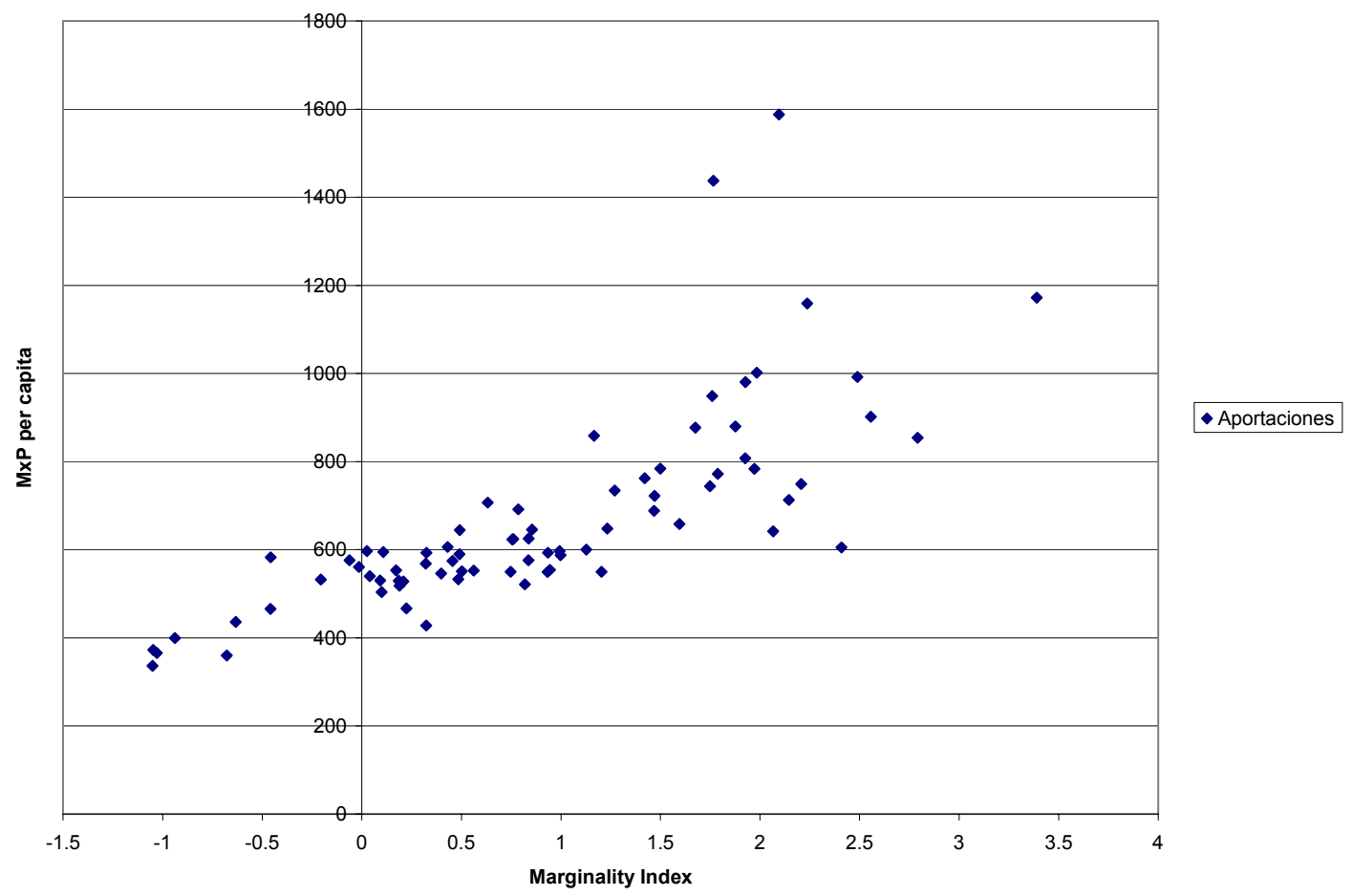

Source: Bank staff calculations.

According to the previous graphs, it seems that poor municipalities received more aportaciones than rich municipalities. Small municipalities tend to be poorer ones, and the formula for some funds gives a minimum amount to each municipalities-leading to higher per capita transfers in small municipalities, but making essentially no difference in the large municipalities. To remove this effect of size, we regressed the aportaciones on the log of population and then plotted the residual (the distribution of the transfers not accounted for by size) against the marginality index, indicating poverty. With this method, Guerrero seems to give more to poor municipalities than to rich municipalities (Figures 17 and 18). In Chiapas, on the other hand, the relationship is less strong and, if anything is negative. This might be a result of Zapatista municipalities (rural and among the most poor) getting less resources during the conflicts of the 1990s. 
Figure 17. Aportaciones To Municipalities (Net of Size Effect) in Chiapas.

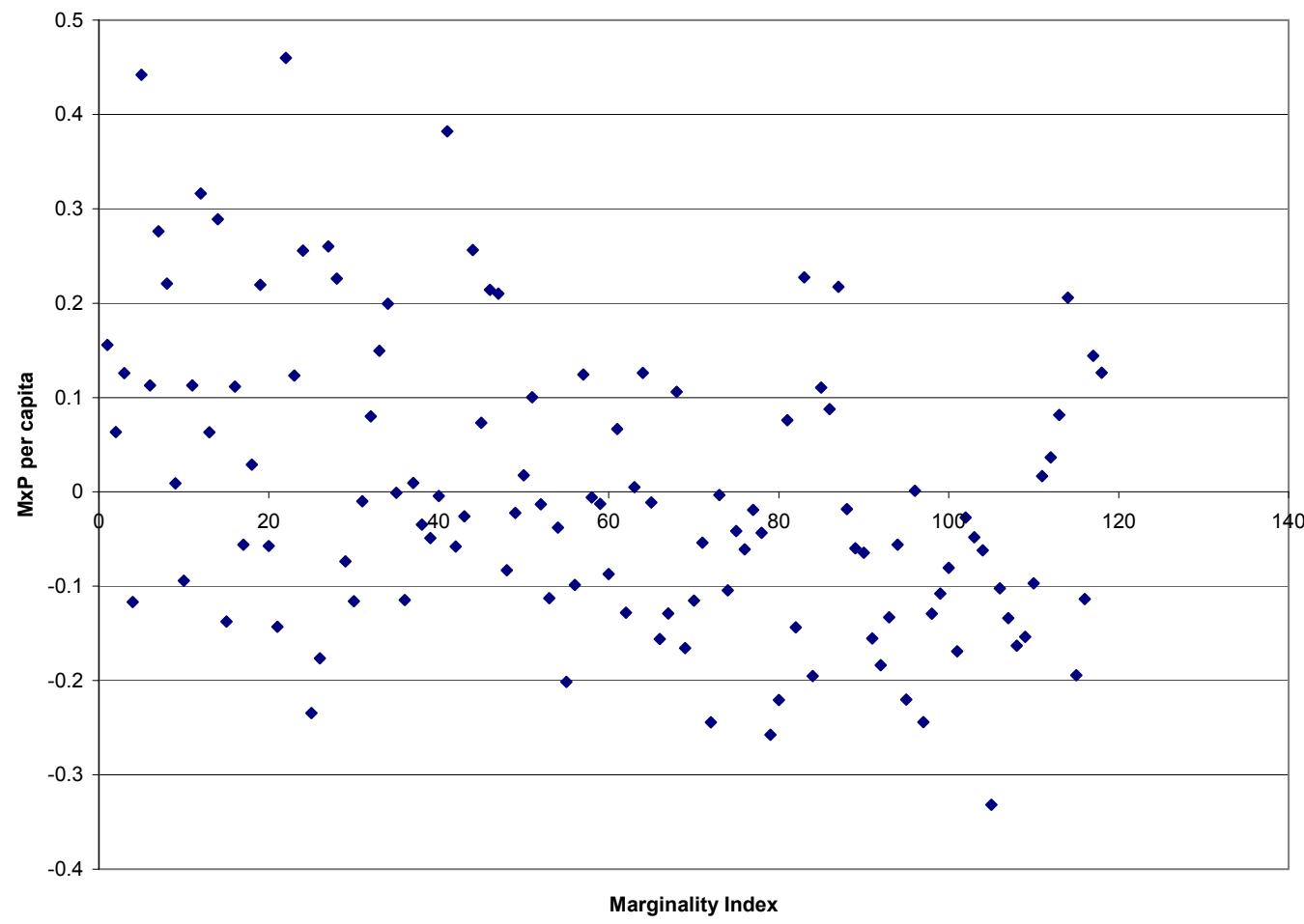

Source: Bank staff calculations.

Figure 18. Aportaciones to Municipalities (Net of Size Effect) in Guerrero

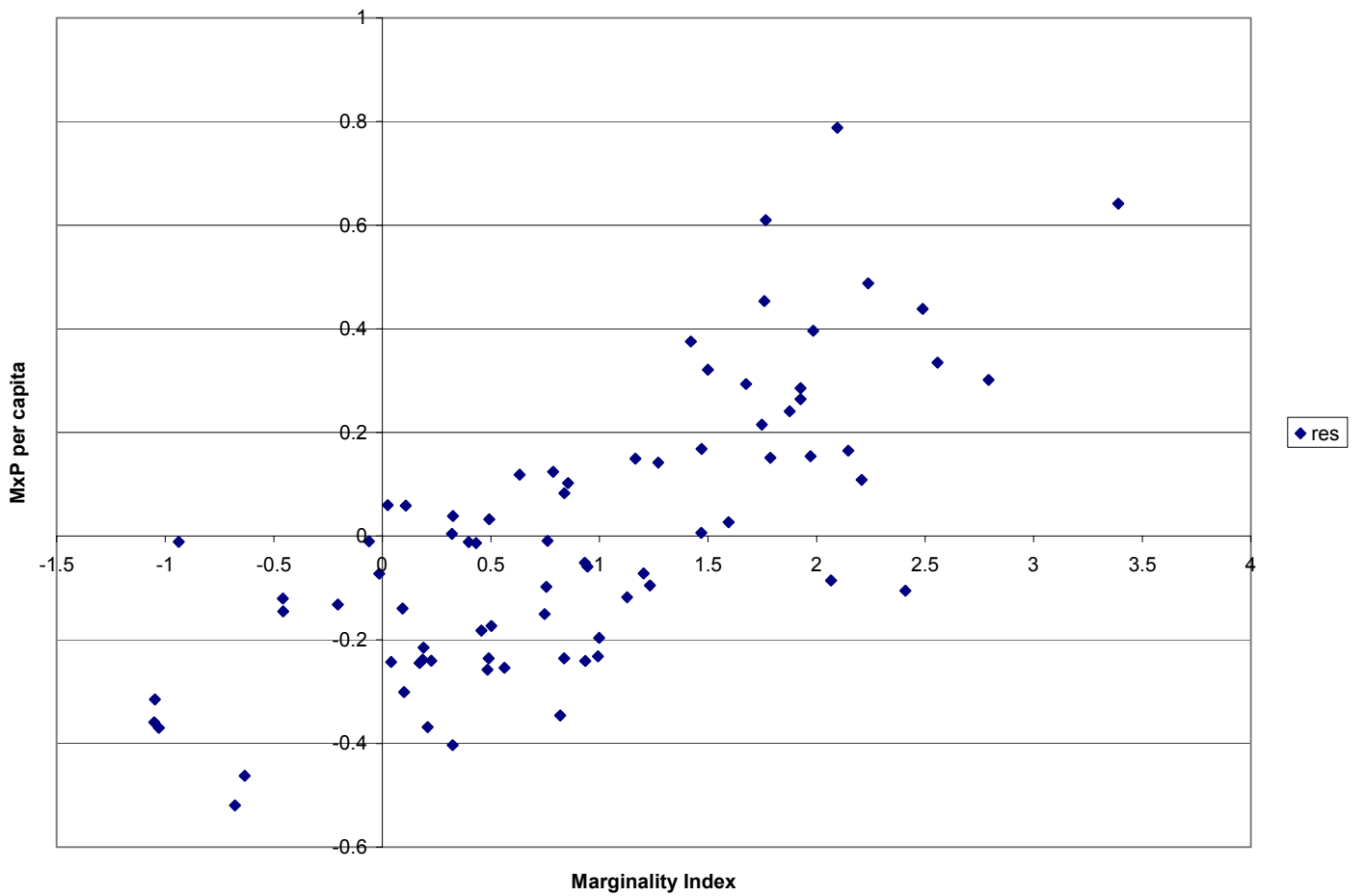

Source: Bank staff calculations. 